\title{
Calcium Excitability and Oscillations in Suprachiasmatic Nucleus Neurons and Glia in vitro
}

\author{
Anthony N. van den Pol, ${ }^{1}$ Steven M. Finkbeiner, ${ }^{2}$ and Ann H. Cornell-Bell ${ }^{3}$ \\ 'Section of Neurosurgery, ${ }^{2}$ Section of Molecular Neurobiology, and ${ }^{3}$ Department of Cell Biology, Yale University School of \\ Medicine, New Haven, Connecticut 06510
}

Converging lines of evidence suggest that the hypothalamic suprachiasmatic nucleus (SCN) is the site of the endogenous biological clock controlling mammalian circadian rhythms. To study the calcium responses of the cellular components that make up the clock, computer-controlled digital video and confocal scanning laser microscopy were used with the $\mathrm{Ca}^{2+}$ indicator dye fluo-3 to examine dispersed $\mathrm{SCN}$ cells and SCN explants with repeated sampling over time. $\mathrm{Ca}^{2+}$ plays an important second messenger role in a wide variety of cellular mechanisms from gene regulation to electrical activity and neurotransmitter release, and may play a role in clock function and entrainment.

SCN neurons and astrocytes showed an intracellular $\mathrm{Ca}^{2+}$ increase in response to glutamate and 5-HT, two major neurotransmitters in afferents to the SCN. Astrocytes showed a marked heterogeneity in their response to the serial perfusion of different transmitters; some responded to both $5-\mathrm{HT}$ and glutamate, some to neither, and others to only one or the other. Under constant conditions, most neurons showed irregular temporal patterns of $\mathrm{Ca}^{2+}$ transients. Expression of regular neuronal oscillations could be blocked by the inhibitory transmitter GABA. Astrocytes, on the other hand, showed very regular rhythms of cytoplasmic $\mathrm{Ca}^{2+}$ concentrations with periods ranging from 7 to $20 \mathrm{sec}$. This periodic oscillation could be initiated by in vitro application of glutamate, the putative neurotransmitter conveying visual input to the SCN critical for clock entrainment. Long-distance communication between glial cells, seen as waves of fluorescence moving from cell to cell, probably through gap junctions, was induced by glutamate, 5-HT, and ATP. These waves increased the period length of cellular $\mathrm{Ca}^{2+}$ rises to 45-70 sec. Spontaneously oscillating cells were common in culture medium, serum, or rat cerebrospinal fluid, but rare in HEPES buffer.

One source for cytoplasmic $\mathrm{Ca}^{2+}$ increases was an influx of extracellular $\mathrm{Ca}^{2+}$, as seen under depolarizing conditions in about $75 \%$ of the astroglia studied. All neurotransmitterinduced $\mathrm{Ca}^{2+}$ fluxes were not dependent on voltage changes, as $\mathrm{Ca}^{2+}$ oscillations could be initiated under both normal and

\footnotetext{
Received June 5, 1991; revised Feb. 7, 1992; accepted Feb. 11, 1992.

Research was supported by NIH Grants NS 16296 and NS 10174 and the Air Force Office of Scientific Research. We thank Dr. S. J Smith for generous suggestions relating to digital video microscopy, Drs. M. Cooper, F. E. Dudek, and J. Miller for helpful advice, and Dr. J. C. Chisolm, J. N. Davis, and P. Thomas for helping with ratio imaging experiments.

Correspondence should be addressed to Anthony N. van den Pol, Section of Neurosurgery, Yale University School of Medicine, 333 Cedar Street, New Haven, CT 06510 .

Copyright $(\mathcal{C} 1992$ Society for Neuroscience $0270-6474 / 92 / 122648-17 \$ 05.00 / 0$
}

depolarizing conditions. Since neurotransmitters could induce a $\mathrm{Ca}^{2+}$ rise in the absence of extracellular $\mathrm{Ca}^{2+}$, the mechanisms of ultradian oscillations appear to depend on cycles of intracellular $\mathrm{Ca}^{2+}$ fluxes from $\mathrm{Ca}^{2+}$-sequestering organelles into the cytoplasm, followed by a subsequent $\mathrm{Ca}^{2+}$ reduction.

In the adult SCN, fewer astrocytes are found than neurons, yet astrocytes frequently surround glutamate-immunoreactive axons in synaptic contact with SCN dendrites, isolating neurons from each other while maintaining contact with other astrocytes by gap junctions.

Neurons and glia respond to neurotransmitter application with a variety of $\mathrm{Ca}^{2+}$ responses; both may play a role in the function of the SCN, and their interaction may explain several aspects of mammalian clock physiology not easily explained solely on the basis of our current understanding of axonally mediated neurotransmission.

The response of suprachiasmatic nucleus (SCN) cells to glutamate and other transmitters found in SCN afferent axons includes both transient $\mathrm{Ca}^{2+}$ elevations and ultradian (with a period less than $24 \mathrm{hr}$ ) oscillations. To study these cellular responses, we used digital video and confocal laser microscopy with the $\mathrm{Ca}^{2+}$ indicator dye fluo-3. This video approach allows the study of the $\mathrm{Ca}^{2+}$ behavior of individual cells as well as the behavior of aggregates or interactive groups of cells over time. $\mathrm{Ca}^{2+}$ plays a crucial second messenger role in a wide variety of cellular events. The importance of $\mathrm{Ca}^{2+}$ is suggested by the apparent absence of circadian rhythms of 2-deoxyglucose uptake and firing rate in the SCN in vitro if calcium was removed from the buffer (Shibata et al., 1984, 1987). In the present study, responses of both neurons and astroglia were studied.

Several models of biological clock timekeeping are based on the interaction of cellular oscillators (Pittendrigh, 1974). The $\mathrm{SCN}$, the putative site of the circadian timekeeper in mammals (Moore and Eichler, 1972; Stephen and Zucker, 1972; Rusak and Zucker, 1979; van den Pol and Powley, 1979), has tacitly been assumed to function by neuronal communication mediated by neurotransmitter release. However, recent experiments blocking sodium-dependent action potentials and related neurotransmitter release with TTX (Schwartz et al., 1987; Meijer and Rietveld, 1989; Schwartz, 1991) that failed to block timekeeping have suggested that classical $\mathrm{Na}^{+}$-dependent axonal neurotransmission may not be required for timekeeping or for cellular orchestration within the SCN. The orchestrated metabolic rhythms of SCN cells found prior to synaptogenesis (Reppert and Schwartz, 1984) are also not easily reconciled with a 
clock model based solely on conventional synaptic axonal ncurotransmission.

Of particular importance to circadian rhythms is the transmitter released from the optic nerves that entrains the endogenous rhythm to the ambient light cycle. Glutamate is the best transmitter candidate for mediation of visual input to the $\mathrm{SCN}$, as it is released in the $\mathrm{SCN}$ by optic nerve stimulation (Shibata et al., 1986) and causes a phase shift in circadian rhythms (Meijer et al., 1988). Optic nerve stimulation induces alterations in electrical field potentials that can be blocked by excitatory amino acid antagonists (Cahill and Menaker, 1987). 6-Cyano-7-dinitroquinoxaline-2,3-dione, a glutamate receptor blocker, blocks the excitatory postsynaptic response to optic nerve stimulation (Kim and Dudek, 1989). In the present article, we used immunogold cytochemistry to show glial cells surrounding presynaptic axons showing high levels of glutamate immunoreactivity in the adult SCN, and we used glutamate, several glutamate agonists, 5-HT, and ATP to study the $\mathrm{Ca}^{2+}$ responses of SCN cells in vitro.

An abstract based on some of this work has been presented (van den Pol et al., 1991).

\section{Materials and Methods}

Cell culture. SCN cells from 1-3-d-old neonatal rats were grown for 18 weeks on glass coverslips coated with collagen and polylysine or polylysine alone, or on untreated glass coverslips (van den Pol et al., 1986). SCN tissue dissected from hypothalamic slices (see below) was incubated in papain $(20 \mathrm{U} / \mathrm{ml}$; Worthington) in a buffer containing $137 \mathrm{mM} \mathrm{NaCl}$, $5 \mathrm{~mm} \mathrm{KCl}, 3 \mathrm{~mm} \mathrm{CaCl}, 1 \mathrm{~mm} \mathrm{MgCl}, 10 \mathrm{~mm}$ HEPES, and $25 \mathrm{~mm}$ glucose on an oscillating Nutator at $37^{\circ} \mathrm{C}$ for $45 \mathrm{~min}$. Enzymatic action was stopped by the addition of $1.5 \mathrm{mg} / \mathrm{ml}$ trypsin inhibitor and $1.5 \mathrm{mg} /$ $\mathrm{ml}$ bovine serum albumin, fraction $\mathrm{V}$ (Sigma). Cells were disaggregated with gentle passage through a fire-polished pipette previously coated with silicon (Prosil21, PCR, Gainesville, FL), used to reduce cell sticking and damage. Disaggregated cells were grown in low (about 2000 neurons) or high densities (about 10,000 neurons) in the middle of the coverslip. Coverslips pretreated with polylysinc $(540 \mathrm{kDa})$ werc subsequently rinsed in five changes of sterile water. Neurons growing with confluent or nonconfluent glial cultures were used. An average of two brains were used for one glass coverslip for high density cultures. GIBCO Dulbecco's minimal essential medium (MEM) was supplemented with $10 \%$ fetal bovine serum (GIBCO and Hyclone), $50 \mathrm{U} / \mathrm{ml}$ penicillin and streptomycin and serum extender (Collaborative Research). Cultures were maintained in a Napco 6100 incubator at $37^{\circ} \mathrm{C}$ and $5 \% \mathrm{CO}_{2}$.

We also cultured explants of SCN made from sections of the anterior hypothalamus. The hypothalami and preoptic area were removed from 3-4-d-old neonatal rats and cut into 300-400 $\mu \mathrm{m}$-thick sections held in $4^{\circ} \mathrm{C} \mathrm{Ca}^{2+}$-free buffer. Under a high-magnification Nikon stereo operating microscope, illuminated from above with a fiber optic light source or from below by substage light, we used sharpened round tubes with an inner diameter of 200 or $325 \mu \mathrm{m}$ to punch out the SCN. The area of the SCN can be identified by its position at the ventral surface of the hypothalamus, on either side of the third ventricle, and directly above the optic chiasm. Sections that did not show sufficient anatomical features to allow identification of the correct regions were discarded. Histological verification of these punches was done by staining the remaining tissue slice before or after fixation with $10 \%$ formalin with $0.1 \%$ propidium iodide for $20 \mathrm{~min}$. Slices with the SCN punched out were examined with a Bio-Rad confocal laser scanning microscope with an argon ion laser and a Texas red filter set. On control slices, the SCN was visible as a tightly clustered group of cells stained with propidium iodide situated above the optic chiasm and at the bottom of the third ventricle. Some punches either were cultured without cell disaggregation in the Napco 6100 incubator, or alternatively were put on glass coverslips, and adhered with a thin layer of chicken plasma and thrombin, as described by Gahwiler (1981) and Wray et al. (1988). SCN tissue used for dispersed cell cultures included a small number of cells outside the border of the SCN in the region where SCN dendrites extend (van den Pol, 1980). Coverslips with an adhered SCN explant were placed in a test tube in a Bellco cell production roller drum rotating at 10 revolutions/hr kept in a Lab-Line Imperial III incubator at $37^{\circ} \mathrm{C}$.

Digital microscopy. For optical recording, cells were loaded with fluo-3 acetoxymethyl(AM) ester for $45 \mathrm{~min}$ in a HEPES buffer [ $10 \mathrm{~mm}$ HEPES, $25 \mathrm{~mm}$ glucose, $137 \mathrm{mM} \mathrm{NaCl}, 5.3 \mathrm{~mm} \mathrm{KCl}, 3 \mathrm{~mm} \mathrm{CaCl}, 1 \mathrm{~mm} \mathrm{MgCl}$, $1 \mu \mathrm{M}$ tetrodotoxin (TTX), $\mathrm{pH}$ 7.4], and then placed in a chamber allowing sequential perfusion of different transmitters and agonists on the stage of a Zeiss IM35 inverted microscope (Cornell-Bell et al., 1990, van den Pol et al., 1990). TTX was used to block voltage-dependent sodium channels and axon action potentials. Since the clock operates in the presence of TTX (Schwartz et al., 1987), many of our experiments parallel conditions under which the clock might operate in the absence of axonal transmission mediated by voltage-dependent sodium channels. A high potassium buffer was similar, except that $\mathrm{KCl}$ was increased to $56 \mathrm{~mm}$, and $\mathrm{NaCl}$ was reduced to $86 \mathrm{~mm}$. A zero-calcium buffer contained no $\mathrm{CaCl}_{2}$, but did contain $1 \mathrm{~mm}$ EGTA. For some experiments studying aspartate and $N$-methyl-D-aspartate (NMDA), $\mathrm{MgCl}_{2}$ was deleted from the buffer, and $4 \mu \mathrm{m}$ glycine was added.

The intensity of fluorescence of fluo-3 increases in the presence of $\mathrm{Ca}^{2+}$, and the dye has excellent spatial and temporal resolution. The high sensitivity was crucial for long recordings where we needed to avoid phototoxicity, and allowed us to work with very low light levels. Furthermore, fluo-3 could be detected both with fluorescent microscopy and with argon laser confocal microscopy. Ratio imaging dyes such as fura- 2 that require more intense light of a shorter wavelength were unsuitable for many of our experiments due to the higher level of phototoxicity over the long recording periods with images averaged every second. Among all the available $\mathrm{Ca}^{2+}$ indicators, fluo-3 provides the largest optical signal per molccule and thus allows for the detection of transients in the smallest possible cytoplasmic volume. With the increased sensitivity of fluo-3, subtle changes in $\mathrm{Ca}^{2+}$ were more easily detected than with fura-2.

Video images were collected with a Hamamatsu 2400 SIT camera interfaced with an Imaging Technology 151 video processor and IBM AT computer, and one video frame was stored on a Panasonic 2023 laser disk recorder every sec. To reduce the possibility of phototoxicity, a computer-controlled shutter completely blocked light for $650 \mathrm{msec}$ of each second, and neutral density filters were used to block $99 \%$ of the light emitted by the mercury light source when the shutter was open. Fluorescent filtration used was the same as used for fluorescein visualization. Data are expressed as a change in fluorescence over baseline fluorescence $\left(\Delta F / F_{0}\right)$. The fluorescent level of each cell under normal conditions served as its own basclinc $\left(F_{0}\right)$, and was corrected for spatial heterogeneity of the video field, as well as for the video gain and offset, and differences in cell esterase activity, by including with each experiment a video record of each cell with different neutral density filters $(1 \%, 2 \%, 3 \%$ transmittance). This allowed a comparison of different cells under the same experimental conditions when the data were examined as a change in $\mathrm{Ca}^{2+}$-induced fluo-3 fluorescence over the baseline corrected fluorescence $\left(\Delta F / F_{0}\right)$ (Cornell-Bell et al., 1990; van den Pol et al., 1990; Cornell-Bell and Finkbeiner, 1991; Finkbeiner, 1991). As previously described with this type of perfusion apparatus, the time from turning on the switch initiating agonist flow to the point that it reached the cells was about 6 sec.

Due to the thickness of the SCN explants, the fluorescent microscope described above could not resolve cellular detail. Instead, we used the confocal scanning laser microscope described previously with a fluorescein filter set. This allowed making digital recordings of an optical section taken within a fluo-3-labeled SCN explant. The intensity of the scanning laser beam was attenuated with a $1 \%$ transmittance neutral density filter. The shutter blocking the laser was set to open immediately after the scan was initiated. As described above, different neutral density filters $(1 \%, 3 \%$ transmittance) were used to determine corrected fluorescence values.

For the ratio imaging experiment, cells were loaded in $5 \mu \mathrm{M}$ fura-2 AM ester in HEPES buffer for $30 \mathrm{~min}$ in the incubator, and studied with a Nikon $40 \times$ (numerical aperture, 1.3) UV-passing quartz objective with either 340 or $380 \mathrm{~nm}$ excitation from a xenon light source. Intensities were collected through a $480-520$ band pass filter. Calibration was based on $100 \mu \mathrm{M}$ ionomycin in the presence of $10 \mathrm{mM} \mathrm{Ca}^{2+}$ for maximum bound dye, and chelation with EGTA for minimum. A $10-\mu \mathrm{m}$-diameter aperture circle over the respective cell bodies was used for data collection.

To test whether astroglia were dye coupled, which is an indication that gap junctions exist between cells, patch-type glass pipettes with a 

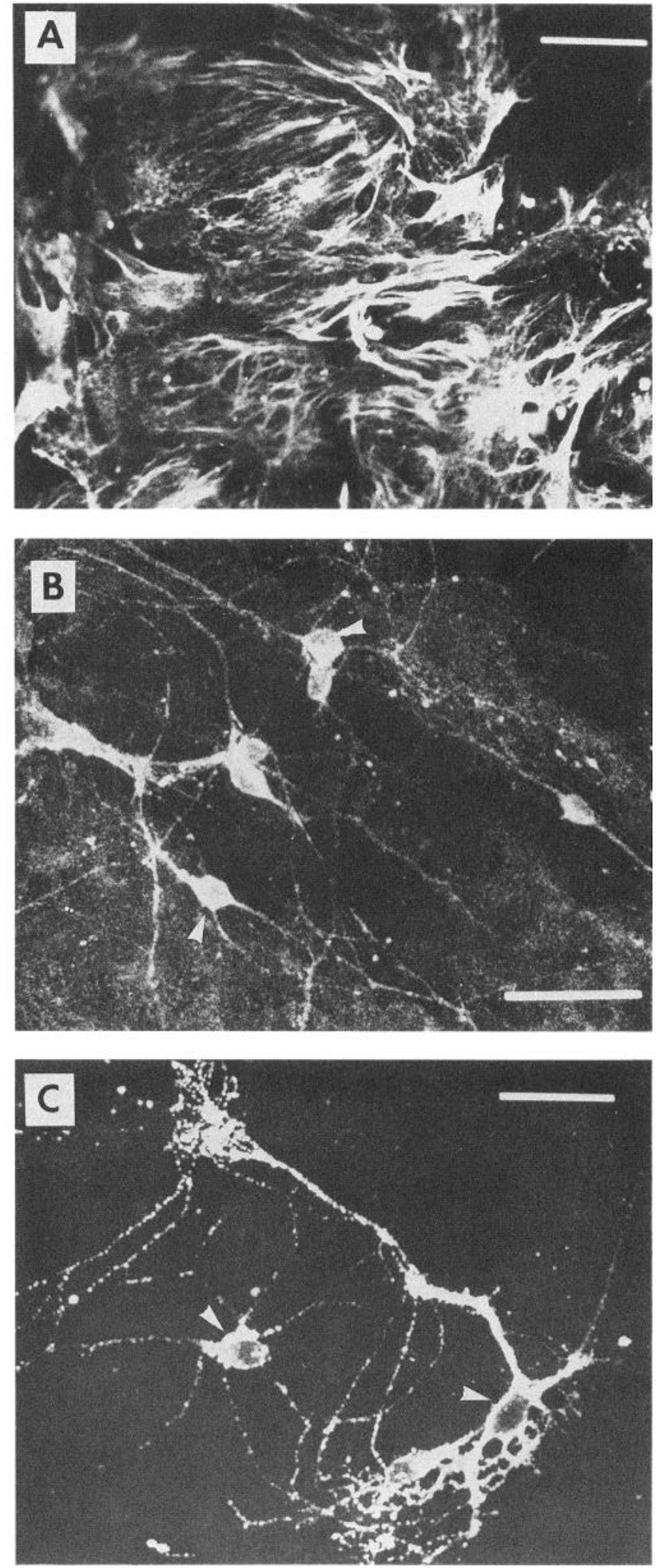

Figure 1. Immunocytochemistry of neurons and astroglia. $A$, On this and the other images in this figure, confocal microscopy was used to obtain images. This micrograph shows $\mathrm{SCN}$ glial cells stained with glial fibrillary acidic protein antiserum. $B$, Neurons are stained with neurofilament antiserum. $C$, Neurons labeled with tetanus toxin. Glial cells on which the neurons in $B$ and $C$ are growing are not labeled with the neuronal markers. Scale bars, $50 \mu \mathrm{m}$.
A

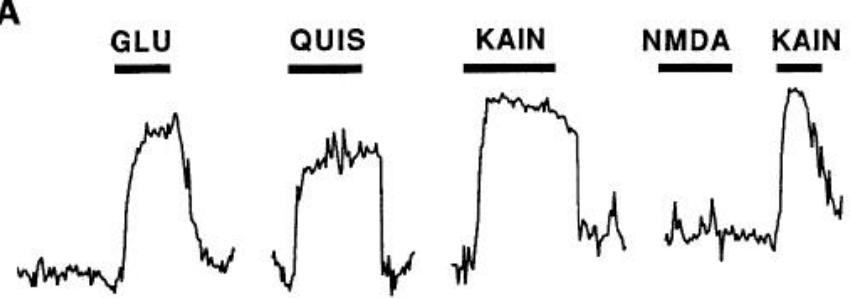

$70 \% \Delta F / F$

$50 \mathrm{~s}$

B

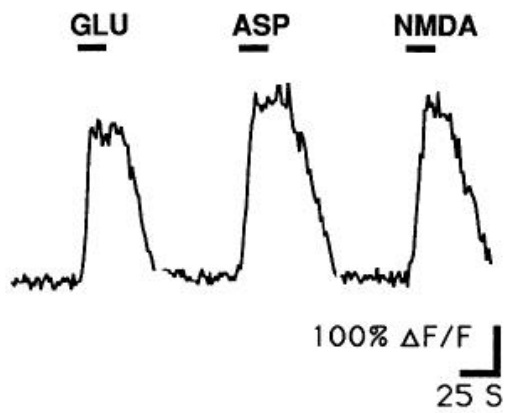

Figure 2. Neuron $\mathrm{Ca}^{2+}$ responses illustrated here are expressed as the change in fluorescence over baseline fluorescence $(\Delta F / F)$ as described in Materials and Methods. A, A single SCN neuron showed a strong increase in $\mathrm{Ca}^{2+}$ in response to $30 \mu \mathrm{M}$ glutamate, quisqualate, and kainate, but not to NMDA. $B$, An SCN neuron responds to aspartate, NMDA, and glutamate (all at $30 \mu \mathrm{M}$ ) in the absence of magnesium and presence of $4 \mu \mathrm{M}$ glycine.

tip internal diameter of about $1 \mu \mathrm{m}$ were filled with 6-carboxyfluorescein, a small fluorescent molecule that diffuses through gap junctions. During observation on the video screen with a combination of videointensified differential interference contrast optics and fluorescent illumination, single cells were filled with the dye by intracellular injection after a membrane seal was obtained, and 10 min later the pipette was removed.

Immunocytochemistry. Rabbit antiserum against glutamate was made with glutamate conjugated by glutaraldehyde to keyhole limpet hemocyanin. The antibody recognized only glutamate and not other amino acids, as determined with immunodot blot, Western blot, ELISA assays, and amino acid bound to Sepharose beads (van den Pol, 1991). After deeply anesthetizing adult male rats $(250-300 \mathrm{gm})$ with Nembutal, they were perfused transcardially with $3 \%$ glutaraldehyde, and the SCN was removed, treated with $1 \%$ osmium tetroxide and $1 \%$ aqueous uranyl acetate, and embedded in Epon or Araldite. Ultrathin sections were immunostained with $10 \mathrm{~nm}$ colloidal gold (Janssen) as described in detail elsewhere (van den Pol, 1989, 1991; van den Pol and Decavel, 1990), and the presence of immunoreactive boutons and their anatomical relationship to nearby astrocytes was studied.

At the ultrastructural level, neurons could be differentiated from other cells by the morphological presence of synapses, dendrites, and axons, while astrocytes could be recognized by their clumps of glial filaments, absence of synapses, and by the irregular contours of astrocytic processes. To estimate the relative number of glia and neurons with stereology, electron micrographs at $60,000 \times$ magnification were overlaid with a regular pattern of points, the number of superimpositions over different cells was counted, and cell size and the relative number of cells were determined (Palkovits, 1976).

To differentiate glia from neurons in vitro, morphological and cytochemical criteria, including immunostaining with antisera against the plasmalemma molecules neural cell adhesion molecule (NCAM; gift of U. Rutishauser or G. Rougon), L1 (gift of V. Lemmon), tetanus toxin-c fragment (Boehringer-Mannheim), and neurofilaments (68 kDa) (Sternberger), neuropeptides such as neurophysin, vasopressin (gift of M. Sofroniew), and vasoactive intestinal polypeptide (Incstar), and glial fibrillary acidic protein (gift of L. Eng), were used. Secondary antibodies were labeled with colloidal gold or fluorescein. Cells were imaged on 
A

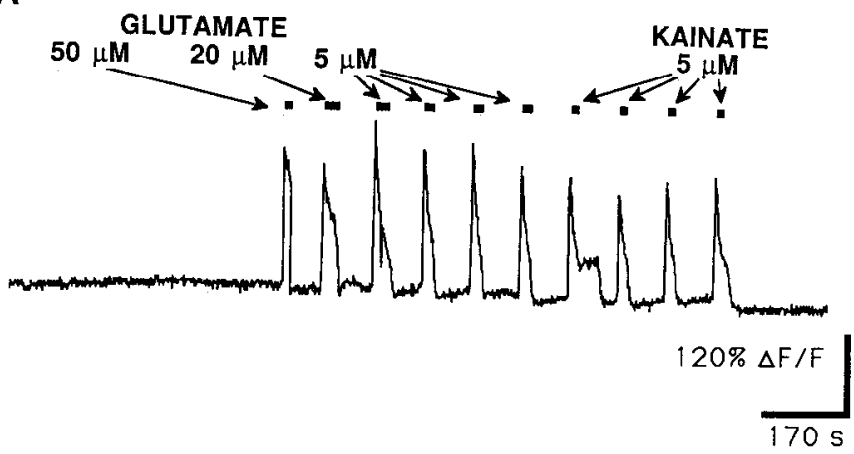

B
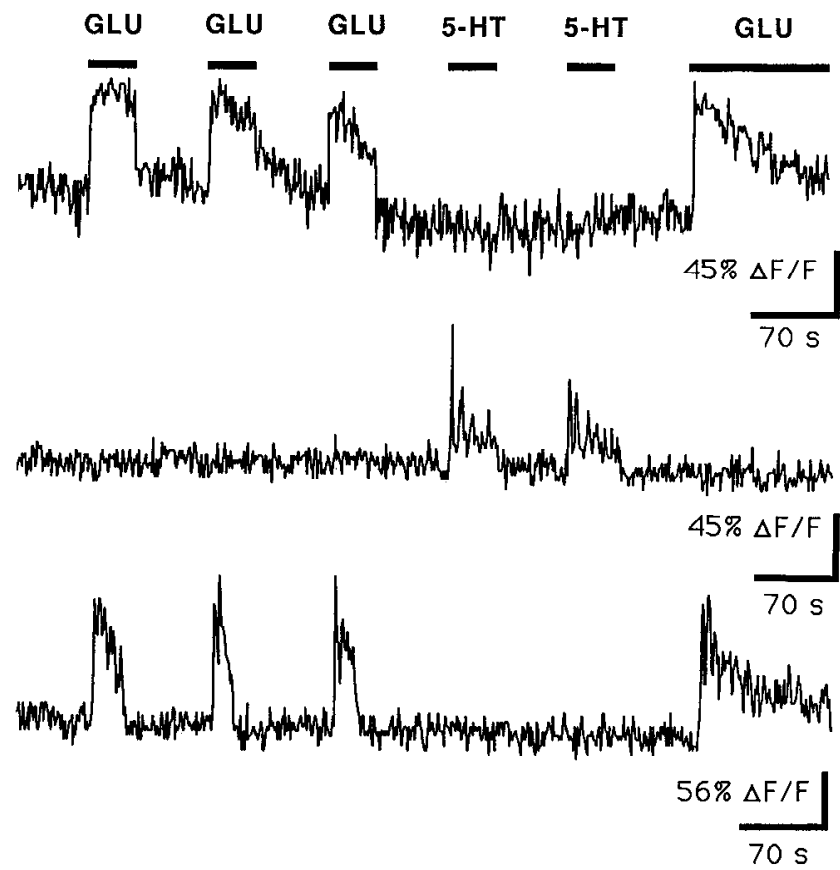

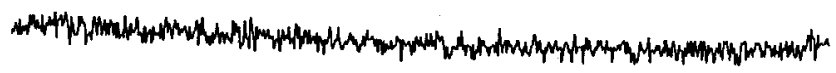

$$
56 \% \frac{\Delta F / F}{70 s}
$$

Figure 3. A, Astrocyte showed an increased intracellular $\mathrm{Ca}^{2+}$ in response to repeated perfusions of glutamate or kainate. $B$, Four astroglia from the same plate recorded simultaneously. Two cells showed a $\mathrm{Ca}^{2+}$ influx in response to glutamate, but not to 5-HT, the third cell showed a response only to 5-HT, and a fourth responded to neither of the transmitters.

either a Zeiss fluorescent microscope or a Bio-Rad confocal scanning laser microscope coupled to an Olympus upright or Zeiss inverted microscope.

\section{Results}

Ncurons had long processes and a semispherical cell body, were immunoreactive for NCAM, L1, and neurofilament protein (Fig. $1 B$ ), and were labeled with tetanus toxin (Fig. 1C). Some neurons were also immunoreactive for vasopressin or neurophysin, substances found in the SCN in vivo. Cells were not used until at least $5 \mathrm{~d}$ after culturing, a time when electron microscopy revealed that synapses were established between neurons. As-

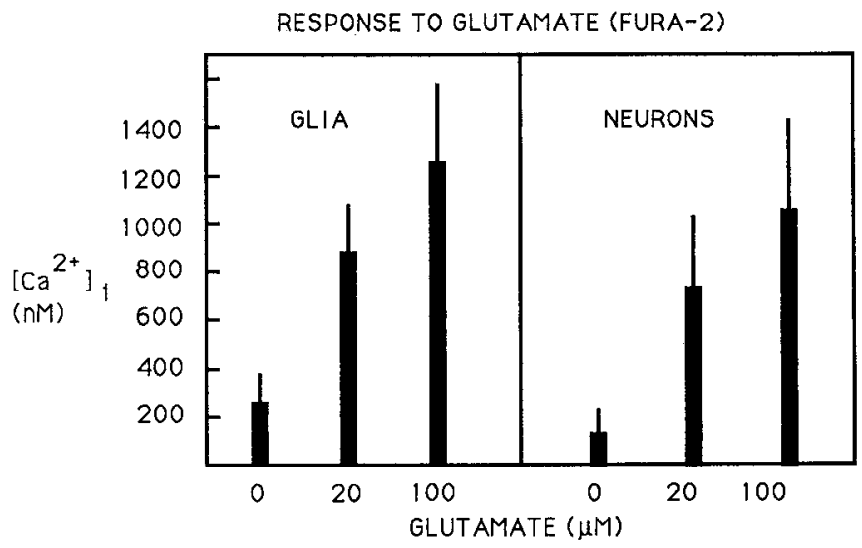

Figure 4. Cytoplasmic $\mathrm{Ca}^{2+}$ measured with fura-2 in five neurons or glia at each glutamate concentration. Error bars are SD.

trocytes had a flat, sheet-like morphology with diameters several times greater than that of neurons and exhibited positive immunostaining for glial fibrillary acidic protein antisera (Fig. 1 $A$ ) and negative staining with $\mathrm{L} 1$ antiserum or neurotransmitterrelated antisera including neurophysin, vasopressin, or vasoactive intestinal polypeptide.

Transmitter response. With optical video analysis, the majority of SCN neurons (183 of 194 cells, 94\%) responded to 100 $\mu \mathrm{M}$ glutamate. $\mathrm{Ca}^{2+}$ rises were also seen in many neurons at glutamate concentrations of $1-5 \mu \mathrm{M}$ (see Fig. 13G,H). Cells responded vigorously to the glutamate agonists kainate and quisqualate (Fig. 2A), but only a minor response to NMDA was seen with the HEPES buffer normally used. When HEPES buffer lacking $\mathrm{Mg}^{+}$and including glycine was used, SCN neurons were found that responded strongly to $30 \mu \mathrm{M}$ NMDA and $30 \mu \mathrm{M}$ aspartate (Fig. $2 B$ ). The estimate of the number of SCN neurons that responded to glutamate is a conservative one; neurons that showed a high initial level of fluo-3 fluorescence may have responded to glutamate with a $\mathrm{Ca}^{2+}$ increase not detectable with the optical constraints of the video system set to analyze faintly fluorescent cells in the same microscope field.

Astrocytes also responded to repeated administrations of 100 $\mu \mathrm{M}$ glutamate (226 of 266 astroglia, $85 \%$ ), kainate (Fig. $3 A$ ), and quisqualate with rapid increases in intracellular $\mathrm{Ca}^{2+}$. Increases in $\mathrm{Ca}^{2+}$-related fluorescence were seen in the cytoplasm of the processes and cell body, and sometimes included the cell nucleus. We did not see any strong response in astrocytes to application of either aspartate or NMDA in either the presence or absence of $\mathrm{Mg}^{+}$or glycine.

Because the percentage of SCN astrocytes that responded to glutamate was lower than the percentage of hippocampal astrocytes that responded to glutamate (100\% of 323 hippocampal astrocytes), we tested whether the cells that did not respond to glutamate perhaps were unable to respond to any $\mathrm{Ca}^{2+}$-inducing agents. Since 5-HT is a prevalent transmitter in afferents to the SCN from the raphe (Agajanian et al., 1969; van den Pol and Tsujimoto, 1985), we compared the glial response to glutamate and 5-HT. The response of SCN glia to serial application of different neurotransmitters was heterogeneous. In one experiment, some glia ( 2 of 13) showed an intracellular $\mathrm{Ca}^{2+}$ increase with glutamate, while others ( 2 of 13 ) in the same video field on the same coverslip responded only to 5-HT. In this group of cells, most cells (9 of 13) did not respond to either transmitter 


\section{NEURON}
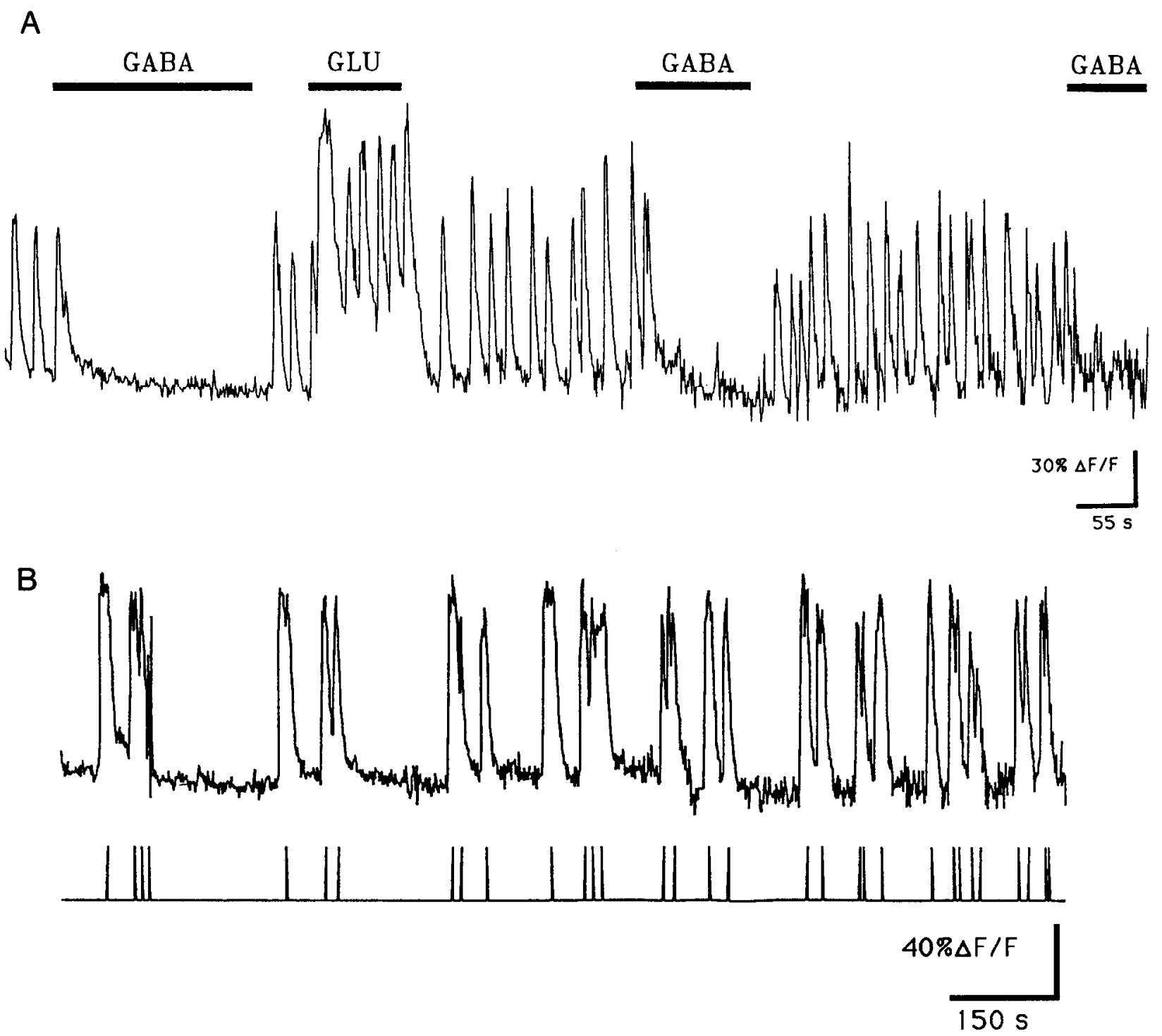

Figure 5. Neuron oscillations. A, An SCN neuron showed a spontaneous regular $\mathrm{Ca}^{2+}$ oscillation that could be consistently blocked with $30 \mu \mathrm{M}$ GABA. Glutamate raised the mean $\mathrm{Ca}^{2+}$ level in this cell, but oscillations continued. This cell was grown in a low neuronal culture density, and the experiments were done in the absence of TTX. $B$, A neuron showed spontaneous fluctuations in intracellular calcium in the presence of TTX. The lowest trace shows $\mathrm{Ca}^{2+}$ peaks in $B$ as single events. The regularity of the neuron is much less than that seen in the glial cells. The variance in periodicity (expressed as the SD as a percentage of the mean) was $4.8 \times$ greater in the neuron (62\%) than in the glial cell (13\%) based on cells in Figure $6 B$. This neuron and the astrocytes in Figure 6 are representative of SCN astrocytes and neurons in general in the presence of TTX.

(Fig. $3 B$ ). In another group of cells cultured under the same conditions, most glia (50 of 51) responded to both 5 -HT and glutamate as shown by the examples in Figure 6. To examine further the heterogeneous response of astrocytes, particularly those that did not respond to glutamate, we also used ATP. ATP is released from many axon terminals (Burnstock, 1986) and has been suggested as a potent agent for increasing intracellular $\mathrm{Ca}^{2+}$ in astrocytes (McCarthy and Salm, 1991). In some coverslips, regions could be found where $90 \%$ of the astrocytes responded to cxtraccllular ATP (sce Fig. $7 A-C$ ), but a response to glutamate could not be detected. These results suggest that a clonal expansion of astrocytes with similar receptive properties may occur. Relatively little $\mathrm{Ca}^{2+}$ response to ATP was found in neurons. $\mathrm{Ca}^{2+}$ rises in the cytoplasm were seen in all responding cells; in some cells a rapid increase in nuclear $\mathrm{Ca}^{21}$ was also detected in phase with the cytoplasmic increase.

To determine how the $\mathrm{Ca}^{2+}$ levels in SCN cells compared with those found in other regions of the nervous system, we used the ratio imaging calcium indicator dye fura- 2 and averaged the responses to glutamate for five cells at each glutamate concentration (Fig. 4). Fura-2 was not used for the long repeated video recording in most of our experiments, due to the greater cellular phototoxicity of parameters required for imaging fura- 2 . The bascline and stimulatcd valucs from SCN ncurons and glia were in the same range as reported for cells from other brain regions (Glaum et al., 1990; Cline and Tsien, 1991).

Calcium oscillations. Neurons with regular oscillations were found in the absence of TTX, and could be perturbed by amino 
A

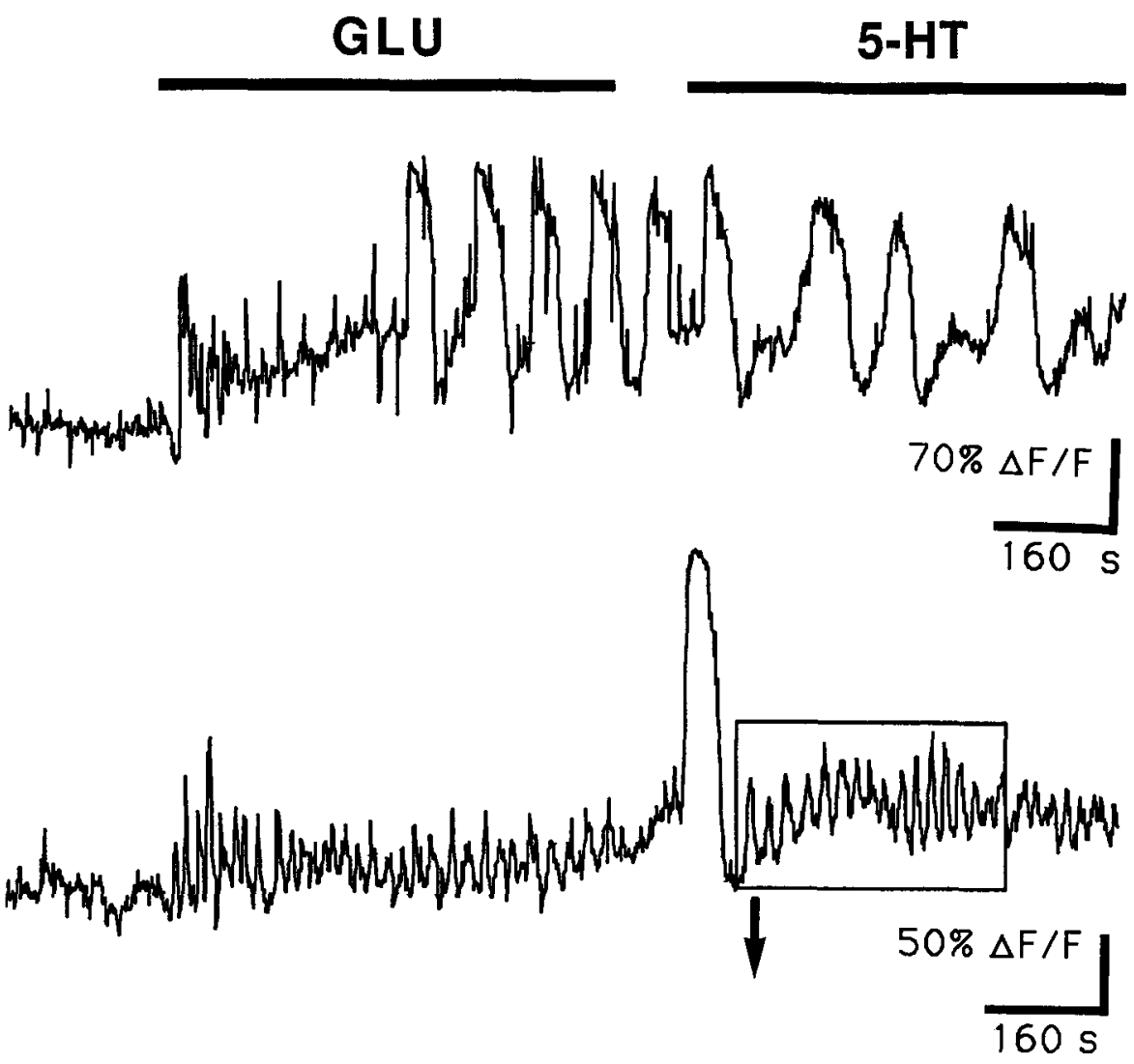

ASTROCYTE

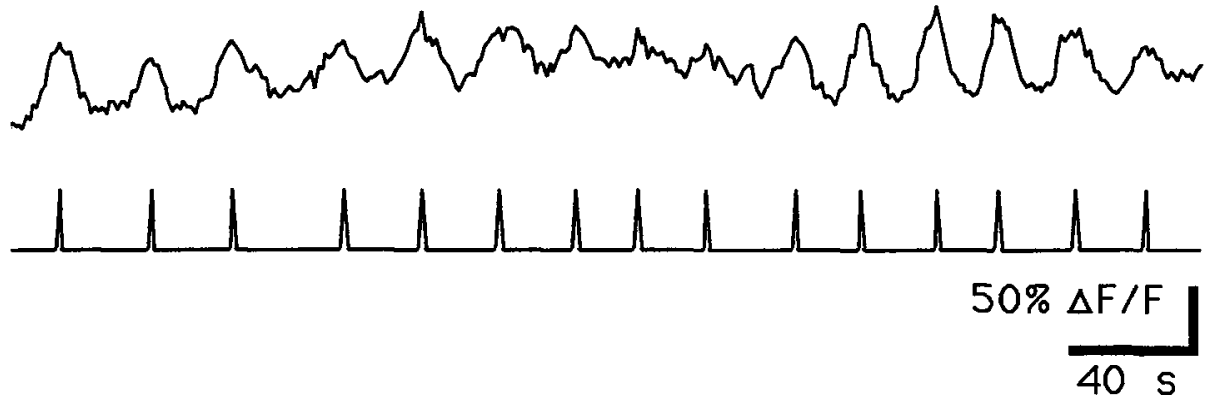

Figure 6. $A$, Two astrocytes responded to glutamate and then to 5-HT with a periodic oscillation of intracellular $\mathrm{Ca}^{2+}$. Note the short periods of the lower cell compared to the long period of the upper cell in the presence of 5-HT. The long period in the upper cell was due to an intercellular $\mathrm{Ca}^{2+}$ wave originating from other glial cells, while the period of the lower cell was due to oscillations originating in that cell. These experiments were done in the presence of $1 \mu \mathrm{M}$ TTX. $B$, Part of the recording in the lower astrocyte in Figure $6 A$ that is boxed is expanded to facilitate examination of the regularity of the periodic response. The lowest trace shows $\mathrm{Ca}^{2+}$ peaks in $B$ as single events. acid transmitters. An example of one neuron that showed a regular $\mathrm{Ca}^{2+}$ oscillation is shown in Figure $5 \mathrm{~A}$. The regular oscillation was blocked by introduction of the inhibitory transmitter GABA (Fig. 5A). When GABA was removed, the oscillations returned. Perfusion of glutamate raised the mean $\mathrm{Ca}^{2+}$ level, and the oscillations continued; in the subsequent absence of glutamate, the mean intracellular $\mathrm{Ca}^{2+}$ level decreased while the oscillations continued. In both neurotransmitter-stimulated and -unstimulated conditions, we found very few neurons with regular $\mathrm{Ca}^{2+}$ oscillations in the presence of TTX, although ir- regular fluctuations of intracellular $\mathrm{Ca}^{2+}$ were not uncommon (Fig. 5B).

Glial cells showed stable periodic oscillations of intracellular $\mathrm{Ca}^{2+}$ in response to applications of neurotransmitters (Fig. 6A,B) in the presence or absence of TTX. The period of the oscillations varied from 7 to $20 \mathrm{sec}$. The regular oscillations of astrocytes were very common, and could easily be induced by neurotransmitter application. Glial cells showed both a $\mathrm{Ca}^{2+}$ rise and $\mathrm{Ca}^{2+}$ oscillations in response to perfusion of glutamate, 5-HT, and extracellular ATP (Fig. 7B,C). 
A
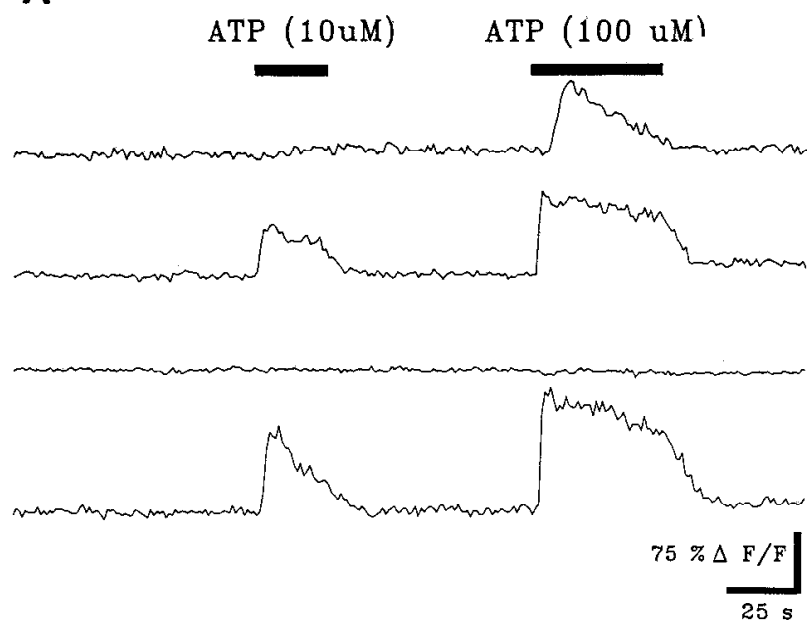

B
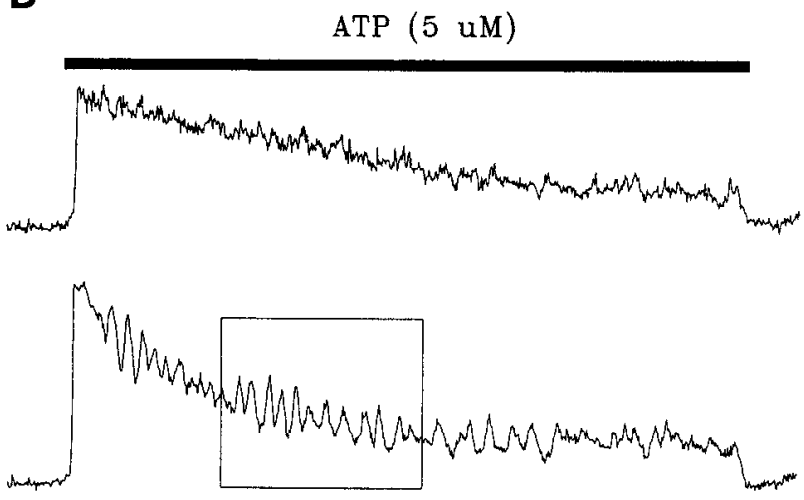

$75 \% \frac{\mathrm{F} / \mathrm{F}}{80 \mathrm{~s}}$

C

$\operatorname{ATP}(5 \quad \mathrm{M})$

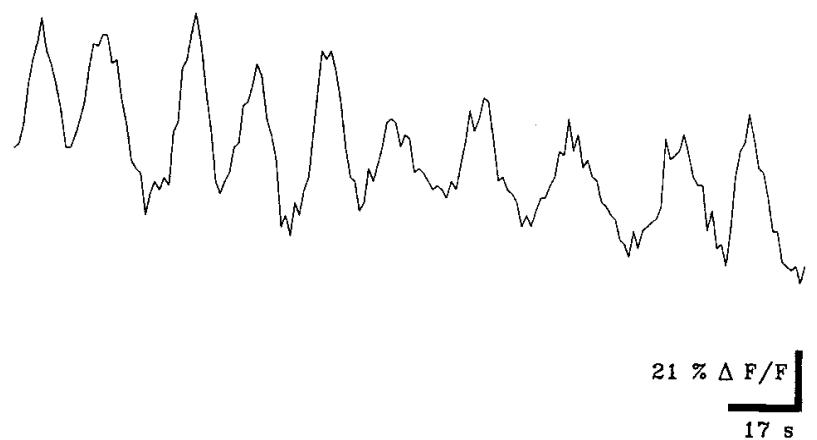

Figure 7. A, The response of four astrocytes to extracellular perfusion of ATP is shown. The top cell responded only to $100 \mu \mathrm{M}$ ATP, while the second and fourth cells responded to $10 \mu \mathrm{M}$ ATP with a small increase in intracellular $\mathrm{Ca}^{2+}$ and a larger increase with $100 \mu \mathrm{M}$ ATP. The third cell shows no response to ATP. B. Two astrocytes responded to $5 \mu \mathrm{M}$ ATP with an immediate increase in intracellular $\mathrm{Ca}^{2+}$. They represent the majority of cells, of which 84 of 91 cells in three experiments showed a $\mathrm{Ca}^{2+}$ rise in response to 5 or $10 \mu \mathrm{M}$ ATP. The bottom cell shows $\mathrm{Ca}^{2+}$ oscillations. Both cells maintained a higher intracellular $\mathrm{Ca}^{2+}$ level until ATP was washed out. $C$, The boxed area in $B$ is expanded to show the $\mathrm{Ca}^{2+}$ oscillations more clearly.
A set of three experiments was designed to classify the $\mathrm{Ca}^{2+}$ oscillations found in SCN astrocytes. In the first one, cells were aeporarized to test whether $\mathrm{SCN}$ glial cells exhibited any voltagedependent $\mathrm{Ca}^{2+}$ fluxes. Figure $8 A$ shows an astrocyte responding to depolarizing concentrations of extracellular $\mathrm{K}^{+}$. Most astrocytes $(70-80 \%)$ showed a cytoplasmic $\mathrm{Ca}^{2+}$ rise that depended on extracellular $\mathrm{Ca}^{2+}$. However, depolarization-induced $\mathrm{Ca}^{2+}$ oscillations were not observed. Since a significant minority of astrocytes did not respond to depolarization with a $\mathrm{Ca}^{2+}$ rise, cells were exposed to $5-\mathrm{HT}$ while depolarized to determine if oscillations could still occur. Figure $8 B$ shows an example of an astrocyte in which 5-HT-induced oscillations were relatively unaffected by depolarization. A third experiment of this series was designed to examine the $\mathrm{Ca}^{2+}$ origin for the transmitterinduced oscillations. Cells were perfused with 5-HT in the presence of $\mathrm{Ca}^{2+}$-free/EGTA-containing buffer; Figure $8 C$ shows that the $\mathrm{Ca}^{2+}$ involved in 5-HT-induced oscillations is primarily from intracellular sources since the response to the transmitter comes in the absence of extracellular $\mathrm{Ca}^{2+}$. A minor contribution from extracellular $\mathrm{Ca}^{2+}$ is suggested by subtle changes in the pattern of oscillation. The period of the oscillation was slightly longer in the absence of extracellular $\mathrm{Ca}^{2+} . \mathrm{Ca}^{2+}$ oscillations in $\mathrm{Ca}^{2+}$-free conditions tend to be superimposed on a different intracellular $\mathrm{Ca}^{2+}$ baseline. In the absence of extracellular $\mathrm{Ca}^{2+}$, the regular oscillations would continue for more than 10 cycles, but would eventually reduce in amplitude, possibly duc to the depletion of intracellular $\mathrm{Ca}^{2+}$ stores.

Whereas astrocytes as a group showed heterogeneous responses to different neurotransmitters, each individual astrocyte showed a stereotyped response to a single transmitter. This is seen both in the rate of rise and fall of $\mathrm{Ca}^{2+}$ after single applications of transmitter as seen in the glutamate responses of cells 1 and 3 in Figure $3 B$, and in the different patterns of oscillations found with longer transmitter stimulations.

Intercellular glial interaction. Tracing $\mathrm{Ca}^{2+}$ waves between adjacent glia (Fig. 9B) indicated that the intercellular pathway is not random, but rather moves very specifically between certain adjacent glia, but not between others, probably due to the presence of a sufficient number of active gap junctions between communicating glial cells. The wave, seen as a slow-moving front of increased fluorescence, traveled at about $15 \mu \mathrm{m} / \mathrm{sec}$ across individual cells, and from cell to cell. Ultrastructural analysis revealed large gap junctions between glia in vitro and in vivo. While neurons may not be able to communicate with one another via voltage-sensitive sodium channels and propagated axonal action potentials in the presence of TTX, $\mathrm{Ca}^{2+}$ waves induced in glial cells by glutamate, 5-HT, or ATP traveled intercellularly probably via gap junctions to other glial cells even in the presence of TTX (Fig. 9A). Intercellular waves of $\mathrm{Ca}^{21}$ movement resulted in slow periodic $\mathrm{Ca}^{2+}$ rises in the individual cells involved in the wave, with peak-to-peak periods ranging from 45 to $70 \mathrm{sec}$, much longer than the periods of cells not showing obvious synchrony with other astrocytes. We found no slow-moving waves of $\mathrm{Ca}^{2+}$ traveling between neurons.

Dye coupling. As the $\mathrm{Ca}^{2+}$ wave may propagate from cell to cell by transfer of small molecules through gap junctions, we examined the dye coupling of astrocytes. Single SCN astrocytes that were intracellularly filled with carboxyfluoresccin showcd movement of the dye to several adjacent neighboring astrocytes in contact with the labeled cell, seen in Figure $13 \mathrm{~B}$. Not all astrocytes were dye coupled with adjacent cells, as shown in Figure $13 C$. 
A

$55 \mathrm{mM} \mathrm{K}+$

काया⿰丿㇅口 Calcium-Free Saline

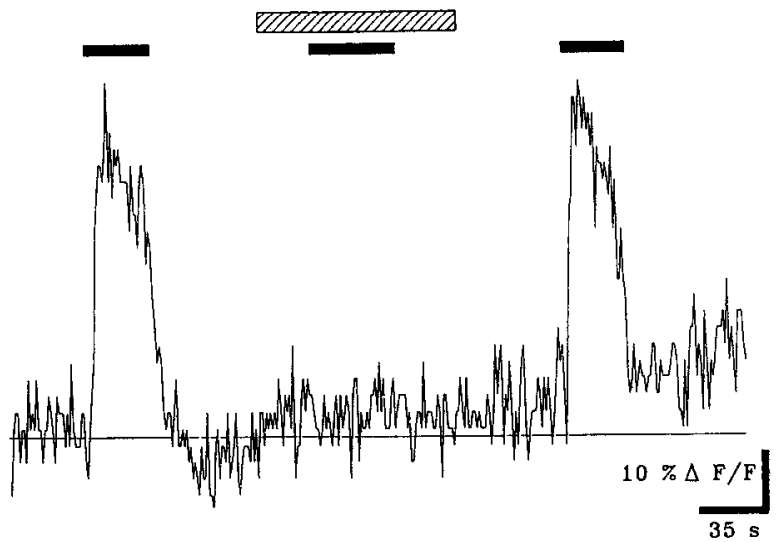

B

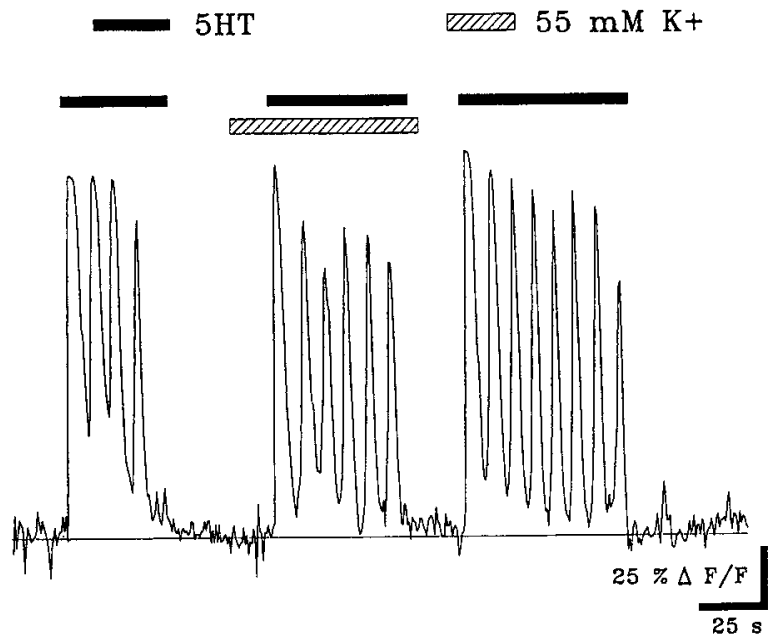

C $5 \mathrm{HT}$ EUIIJ Calcium-Free Saline
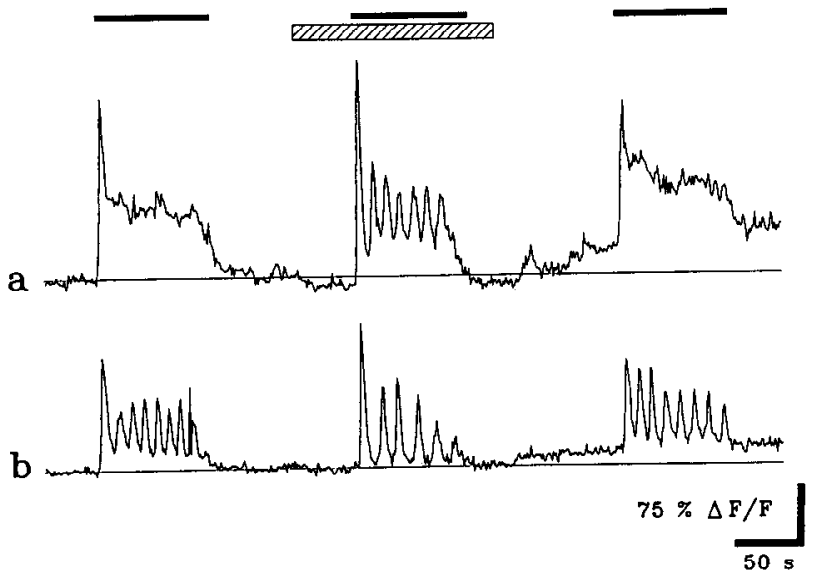

Figure 8. A, An increase in extracellular $\mathrm{K}^{+}$caused a rise in $\mathrm{Ca}^{2+}$ through voltage-gated $\mathrm{Ca}^{2+}$ channels in the plasmalemma. No increase was seen if extracellular $\mathrm{Ca}^{2+}$ was removed; with later perfusion of $\mathrm{Ca}^{2+}$ containing buffer, cells again responded to a $\mathrm{K}^{+}$rise. $B$, Whereas an increase in extracellular $\mathrm{K}^{+}$did not induce a $\mathrm{Ca}^{2+}$ rise, 5-HT induced a $\mathrm{Ca}^{2+}$ rise and $\mathrm{Ca}^{2+}$ oscillations, in both the presence and absence of extracellular $\mathrm{K}^{+} . C$, Two astrocytes showed an increase in $\mathrm{Ca}^{2+}$ and oscillations in $\mathrm{Ca}^{2+}$-free buffer. The oscillations were not detected in the upper cell in the presence of the extracellular $\mathrm{Ca}^{2+}$.
A

GLU
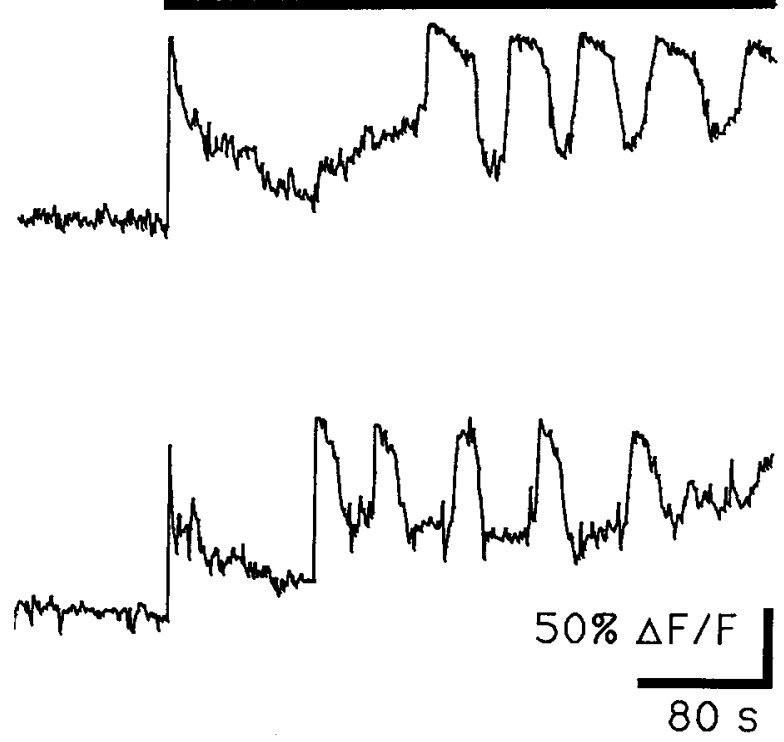

B

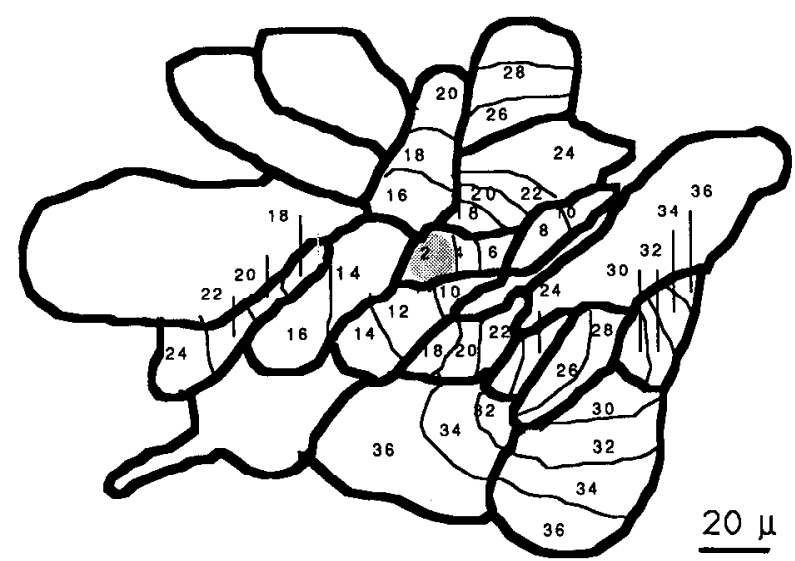

Figure 9. $A$, Waves of $\mathrm{Ca}^{2+}$ spread from one glial cell to the next adjacent one, with several seconds elapsing while the wave passed through a single cell. The intercellular wave can alter the period of the independently oscillating glial cell, increasing the length of the period. The regular rise and fall of $\mathrm{Ca}^{2+}$ is different in two cells from the same coverslip, showing the complex interaction between the individual oscillation and the wave dependent periodic rise and fall in cell $\mathrm{Ca}^{2+}$. These experiments were done in the presence of $1 \mu \mathrm{M}$ TTX. $B$, An increase in intracellular $\mathrm{Ca}^{2+}$ started in the shaded cell (time 2), and traveled from that cell to some, but not all, of the cells in this group. Cell boundarics of single astrocytes are indicated by thick lines. Direct contact is necessary for the signal to be carried from one cell to the next. Approximate movement of the $\mathrm{Ca}^{2+}$ wave (shown by the thin line) at 2 sec intervals as it traveled from cell to cell is indicated by the numbers (sec).

Serum, medium, and rat cerebrospinal fluid. Most of the experiments were done with HEPES buffer, as commonly used with $\mathrm{Ca}^{2+}$ imaging. To recreate more closely the conditions under which these cells are growing, their responses to conditioned medium, nonconditioned medium, and serum were tested. The majority of cells ( $95 \%)$, both neurons and glial cells, showed $\mathrm{a} \mathrm{Ca}^{2+}$ rise when the medium they were growing in was reintroduced after a wash with HEPES buffer. To determine if this response was due to factors released by the cells or was due to the nonconditioned medium, three different media without serum were perfused through the chamber. All three, including 
Serum

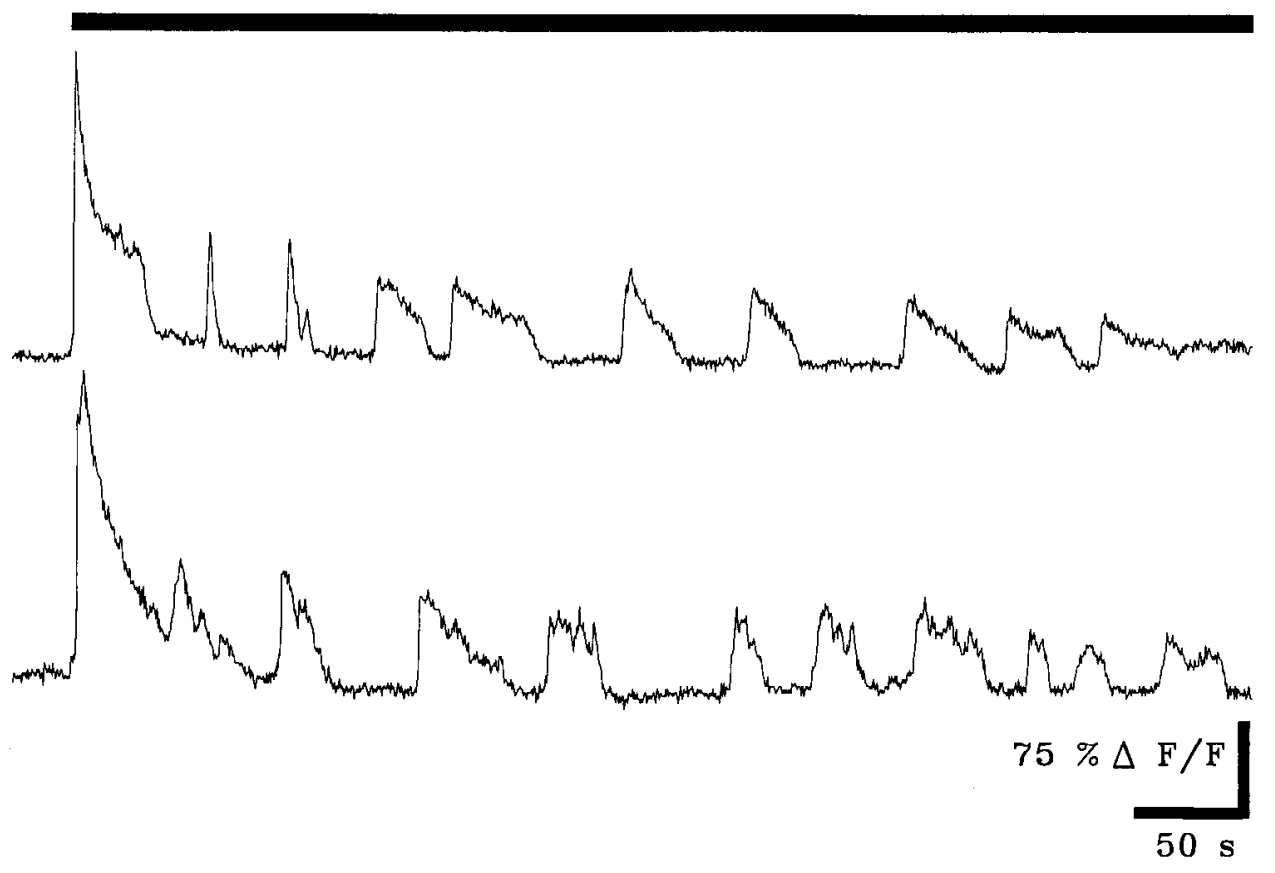

Figure 10. The addition of fetal bovine serum to the HEPES buffer induced a sharp rise in $\mathrm{Ca}^{2+}$ that drops down to the baseline, while $\mathrm{Ca}^{2+}$ oscillations continue in both of these astrocytes.
GIBCO F10, Eagle's MEM, and Dulbecco's MEM, caused an increase in $\mathrm{Ca}^{2+}$ levels in $95 \%$ of the cells tested $(n>100)$. Similarly, fetal bovine serum $(10 \%)$ when added to the HEPES buffer induced $\mathrm{Ca}^{2+}$ rises in $96 \%$ of the cells $(n=109)$ examined (Fig. 10). Similar rèsults were obtained with $10 \%$ horse serum. Chamber perfusion with both serum and medium also caused $\mathrm{Ca}^{2+}$ oscillations in glial cells.

In an attempt to recreate conditions that more closely simulate those that SCN cells might encounter in the rat brain, we used punches that contained blocks of SCN tissue that were not disaggregated with proteolytic enzymes, but instead were cultured whole. Figure 11 shows a slice used for histological verification where a part of SCN was punched out and cultured. Explants were used 4-8 d after culturing. When the fluo-3-loaded cells within the explants were examined with confocal laser microscopy, many of the astrocytes (43 of 55) showed $\mathrm{Ca}^{2+}$ oscillations induced by rat cerebrospinal fluid (CSF) (Fig. 12). Some glial cells showed regular oscillations that continued for the duration of the recording period with cells in the rat CSF (Fig. 13A). The top astrocyte in Figure 12 shows $\mathrm{Ca}^{2+}$ oscillations with an initial period of about $18 \mathrm{sec}$ after introduction of CSF; as the mean $\mathrm{Ca}^{2+}$ level of the cell decreases, a second extended series of oscillations with a period of about $45 \mathrm{sec}$ is seen for the duration of the recording period. Others showed an initial series of oscillations, followed by a return to baseline levels (Fig. 12). The thin optical sectioning capability of the confocal microscope allowed detection of nuclear responses to CSF (Fig. $13 D-F$ ). Some astrocytes that showed regular oscillations in the cytoplasm also showed similar oscillations in the nucleus in phase with cytoplasmic $\mathrm{Ca}^{2+}$ levels. Prior to the addition of rat CSF, we detected no oscillations in any of the cells examined $(n=$ 55). Cells showing extended regular oscillations while incubated in rat CSF lost them when the CSF was replaced with HEPES buffer. Introduction of glutamate induced an additional $\mathrm{Ca}^{2+}$ rise and $\mathrm{Ca}^{2+}$ oscillations.

Astrocytes surround presynaptic glutamate-immunoreactive boutons-ultrastructural immunocytochemistry. Although glu- tamate has been suggested as a primary transmitter in afferent projections to the SCN, supporting immunocytochemical evidence has been lacking. Since we found a glial response to glutamate in vitro, we investigated the morphological relationships between presynaptic boutons immunoreactive for glutamate and nearby astroglia in the intact adult SCN. Some axon terminals in synaptic contact with SCN perikarya and dendrites showed strong immunogold labeling with glutamate antisera. The ratio of gold particles over presynaptic axon to postsynaptic dendrite was $5: 1$, similar to ratios found over glutamatcrgic presynaptic axons in other parts of the brain (Somogyi et al., 1986; Ottersen, 1989; van den Pol, 1991). Astrocyte sheaths surrounded many synaptic complexes, including those in which the presynaptic axon exhibits a high immunoreactivity for glutamate (Fig. 14); these astrocyte processes segregate many neuronal elements from each other.

Glia in the adult SCN occur in numbers somewhat less than the number of neurons, as determined with stereological (Palkovits, 1976) counting of glial cells in electron micrographs from the SCN of adult male rats. Based on percentage of stereological point overlays on glia and neurons and on relative cell size in 60 random fields, the relative number of astroglia per unit volume was estimated to be about $65 \%$ of that of neurons with some variation in different regions of the $\mathrm{SCN}$.

\section{Discussion}

$\mathrm{Ca}^{2+}$ is an important intermediary in a wide variety of cellular mechanisms. With noninvasive digital imaging of $\mathrm{Ca}^{2+}$ in living SCN cells, we have shown a strong neuronal and glial $\mathrm{Ca}^{2+}$ response to neurotransmitters. These were seen either as an increase in $\mathrm{Ca}^{2+}$ levels, or as a change in the patterns of ultradian oscillations. $\mathrm{Ca}^{2+}$ changes in the cytoplasm could serve to influence many of the intracellular systems using $\mathrm{Ca}^{2+}$ as a second messenger. $\mathrm{Ca}^{2+}$ rises detected in the cell nucleus may serve to modulate genomic expression there. The induction of $c$-fos and c-jun by neurotransmitters or cholera toxin may act through $\mathrm{Ca}^{2+}$ second messengers (Gabellini et al., 1991; Trejo and Brown, 


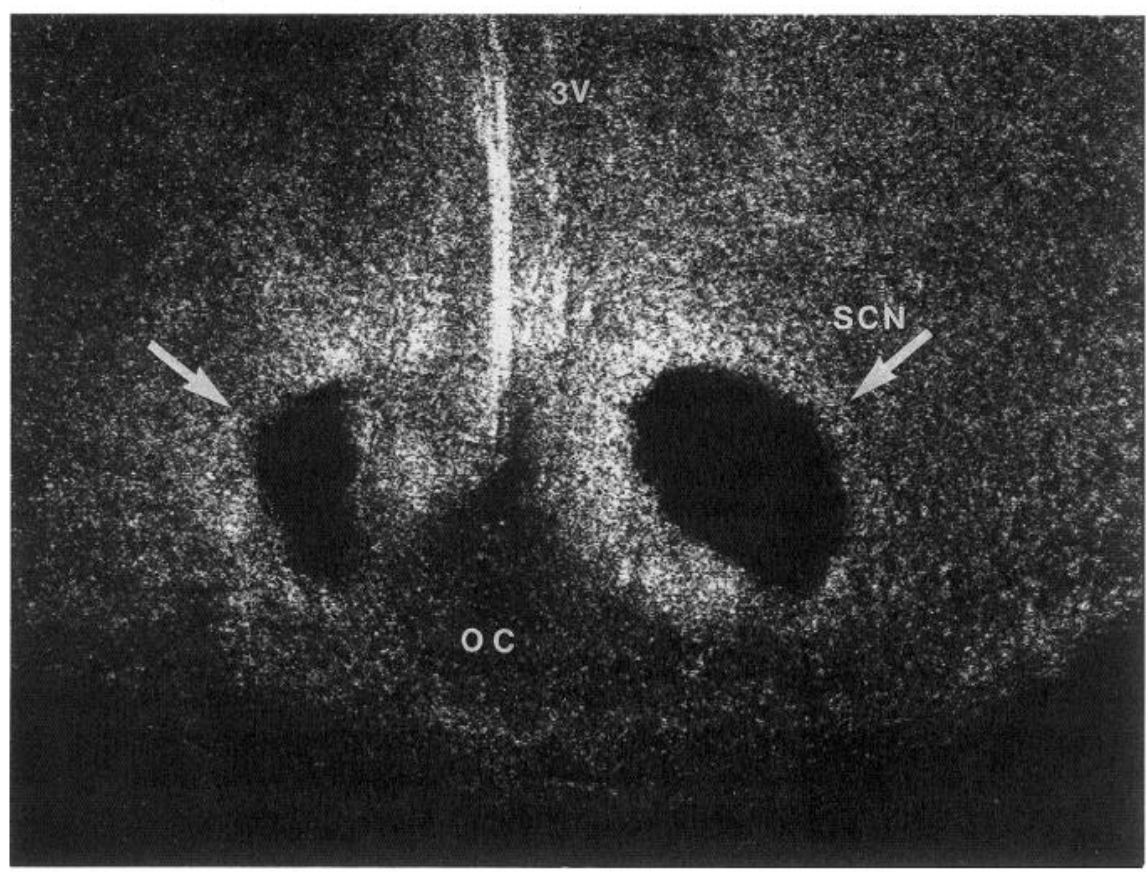

Figure 11. Laser confocal image of a propidium iodide-stained hypothalamic slice of a $3 \mathrm{~d}$ neonatal rat. Part of the SCN on both sides was punched out for culturing (arrows). oc, optic chiasm; $3 v$, third ventricle.
1991). An increase in SCN cell nuclear c-fos and other earlyimmediate gene products can be induced by photic stimulation at certain times of an animal's circadian cycle (Rea, 1989; Kornhauser et al., 1990; Rusak et al., 1990), perhaps through intracellular $\mathrm{Ca}^{2+}$ signaling.

Neuron response to glutamate. Immunocytochemical localization of high levels of glutamate in presynaptic endings in the $\mathrm{SCN}$ adds further support to previous suggestions that glutamate may be an important transmitter here (Shibata et al., 1986; Cahill and Menaker, 1987; Kim and Dudek, 1989). The widespread $\mathrm{Ca}^{2+}$ response of $\mathrm{SCN}$ neurons to glutamate suggests that the relative ineffectiveness of excitotoxic amino acids in killing SCN cells (Peterson and Moore, 1980) is not due either to the lack of glutamate receptors, or to a lack of an increase in intracellular $\mathrm{Ca}^{2+}$, which has been suggested as one cause of cell death after exposure to high levels of excitatory amino acid agonists (Choi, 1988). Whether the reduced toxicity of glutamate in the $\mathrm{SCN}$ is due to a smaller number or different types of glutamate receptors, to differences in second messenger systems related to $\mathrm{Ca}^{2+}$, or to differences in the astrocyte response and uptake of glutamate remains to be determined.

Mechanism of $\mathrm{SCN}$ cellular $\mathrm{Ca}^{2+}$ oscillation. $\mathrm{Ca}^{2+}$ oscillations are found outside the $\mathrm{SCN}$ in other cell types, and have been broadly categorized as either membrane oscillators or cytosolic oscillators according to the site where most of the $\mathrm{Ca}^{2+}$ fluxes occur (Berridge and Galione, 1988; Berridge and Irvine, 1989). Membrane oscillators depend on agonist-induced transmembrane voltage changes to trigger a reciprocal activation of voltage-gated $\mathrm{Ca}^{2+}$ and $\mathrm{Ca}^{2+}$-sensitive potassium channels, resulting in a periodic $\mathrm{Ca}^{2+}$ influx. One example of a membrane oscillator is glucose-stimulated $\mathrm{Ca}^{2+}$ oscillations in pancreatic $\beta$-cells (Sherman et al., 1988; Grapengiesser et al., 1989; Chay, 1990). Cytosolic oscillators involve the periodic release of $\mathrm{Ca}^{2+}$ from an intracellular store; the mechanism may include receptorstimulated inositol turnover, subsequent $\mathrm{Ca}^{2+}$ release from the endoplasmic reticulum, and specific interactions between intracellular elements such as protein kinase $\mathrm{C}$, phospholipase $\mathrm{C}$, and $\mathrm{Ca}^{2+}$ reservoirs other than the endoplasmic reticulum. $\mathrm{A}$ capacitive model of cytosolic oscillators (Putney, 1986) postulates the existence of an intracellular store capable of accumulating cytosolic $\mathrm{Ca}^{2+}$ to a threshold level. Above threshold, additional cytosolic $\mathrm{Ca}^{2+}$ increases serve to stimulate a rapid release of intracellularly stored $\mathrm{Ca}^{2+}$. Aspects of this idea have been incorporated into more complicated models that may explain a wider variety of features of cytosolic oscillators (Goldbeter et al., 1990). Since neurotransmitter stimulation elicits a $\mathrm{Ca}^{2+}$ rise in SCN glia even in the absence of extracellular $\mathrm{Ca}^{2+}$, our data suggest that the neurotransmitter-induced $\mathrm{Ca}^{2+}$ increase, at least under our in vitro conditions, is primarily from intracellular stores, invoking a cytoplasmic oscillatory mechanism (CornellBell et al., 1990; Jensen and Chiu, 1990) rather than a membrane oscillatory system.

Most experiments were done with HEPES buffer of minimal composition; addition of culture media, serum, or CSF to mimic more natural conditions increased the general level of activity of all cells, suggesting that a much greater level of complexity and oscillatory behavior may be occurring in the brain. Extended $\mathrm{Ca}^{2+}$ oscillations were found in astrocytes from $\mathrm{SCN}$ explants incubated in rat CSF, but not when CSF was replaced with buffer.

Regular $\mathrm{Ca}^{2+}$ oscillations in $\mathrm{SCN}$ neurons were detected less often than in astrocytes, and predominantly in the absence of TTX. Astrocyte oscillations in the presence of TTX were very regular. In contrast, neuronal oscillations tended to be sporadic and irregular in the presence of TTX in our in vitro conditions. This suggests that intercellular axosynaptic communication between neurons, or voltage-dependent sodium channels, may play a role in maintaining regular oscillations in neurons. Since there is a positive correlation with transmitter release and intracellular $\mathrm{Ca}^{2+}$, neurons that demonstrated regular cycles of $\mathrm{Ca}^{2+}$ may also release their neurotransmitters in corresponding ultradian cycles. Oscillations in neurons were under neurotransmitter modulation. GABA, an inhibitory transmitter found in half (48\%) of all SCN presynaptic axons (Decavel and van den Pol, 1990), 

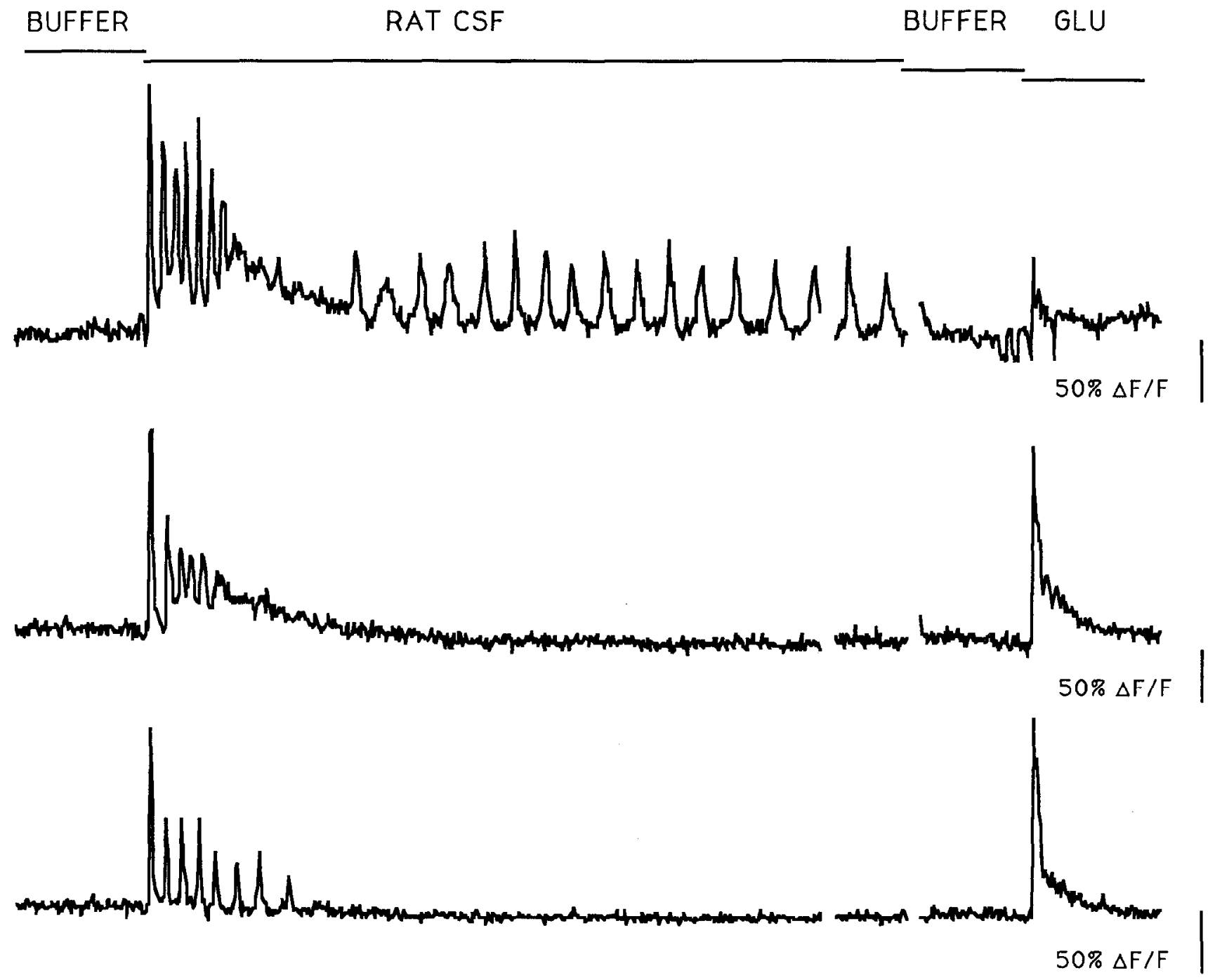

1

1110

TIME (s)

Figure 12. Response of three astrocytes from an SCN explant in vitro studied with laser confocal microscopy. During the first hundred seconds, astrocytes showed no oscillatory behavior in HEPES buffer. When rat CSF was added, all three cells showed an increase in Ca ${ }^{2+}$ and high-amplitude $\mathrm{Ca}^{2+}$ oscillations. The top cell continued to show $\mathrm{Ca}^{2+}$ oscillations throughout the time of examination. The other two cells returned to baseline $\mathrm{Ca}^{2+}$ levels. After $608 \mathrm{sec}$, recordings were stopped to reduce the possibility of phototoxicity of the laser beam; $500 \mathrm{sec}$ later, recordings were again initiated, showing that the cell on top was still oscillating. When the rat CSF was replaced with HEPES buffer, oscillations ceased. All three cells responded with an increase in $\mathrm{Ca}^{2+}$ upon stimulation with $100 \mu \mathrm{M}$ glutamatc.

Figure 13. A, A time series of 24 pseudocolored video micrographs showing a single fluo-3-labeled astrocyte (thick vertical arrow) with a regular $\mathrm{Ca}^{2+}$ oscillation. Green indicates higher levels of fluorescence, and pink indicates lower levels. Images were recorded 5.4 sec apart. The first image is labeled 1 and the last 24 . The image sequence starts in the upper left and reads like a book, as shown by the horizontal arrow. The ultradian rhythm of this cell is very regular, seen by the strong $\mathrm{Ca}^{2+}$ signal in the 5 th, 13 th, and 21 st frames; $\mathrm{Ca}^{2+}$ peaks were 43 sec apart. This sequence is $130 \mathrm{sec}$ long and shows only a part of a sequence 10 times longer in which the cell maintained this steady rhythm. The width of the astrocyte was $55 \mu \mathrm{m}$. $B$, Astrocyte during filling with carboxyfluorescein is on the left (arrow). The same cell 10 min later after the filling patch pipette was removed is seen on the right. Four adjacent cells are also labeled, suggesting dye movement through gap junctions between coupled cells. Width of the filled astrocyte was $42 \mu \mathrm{m}$. C, Another cell in the same culture dish was fillcd with dyc, on the left, and secn 10 min later on the right. Although many other glial cells surrounded this cell, no dye coupling was found in this case. Width of the filled astrocyte was $40 \mu \mathrm{M}$. $D-F$. Confocal laser microscope was set for a thin optical section. In this series of micrographs, the nuclei (arrows) of two astrocytes show a strong response to the introduction of rat CSF to the recording chamber, similar to the response sometimes seen with introduction of neurotransmitter. Fluorescence increased in both the cytoplasm and nucleus. Dark red indicates a low level, bright red a medium level, and yellow a high level of fluorescence. $D$ shows the two cells $5 \mathrm{sec}$ before stimulation, representative of the previous $100 \mathrm{sec}$. $E$ shows the cells 3 sec after initiation of stimulation, and $F$ shows the same field $10 \mathrm{sec}$ later. Width of micrograph is $80 \mu \mathrm{m}$. $G$, A field of fluo-3-loaded SCN neurons prior to transmitter stimulation. $H$, The same field as shown in $G$, but at the time of stimulation with $5 \mu \mathrm{M}$ glutamate. All 15 neurons showed an increase in Ca ${ }^{2+}$ as shown by the increase in their pink coloration in this pseudocolored image. Arrows show the same two neurons in $G$ and $H$. Width of micrograph is $150 \mu$ m. 

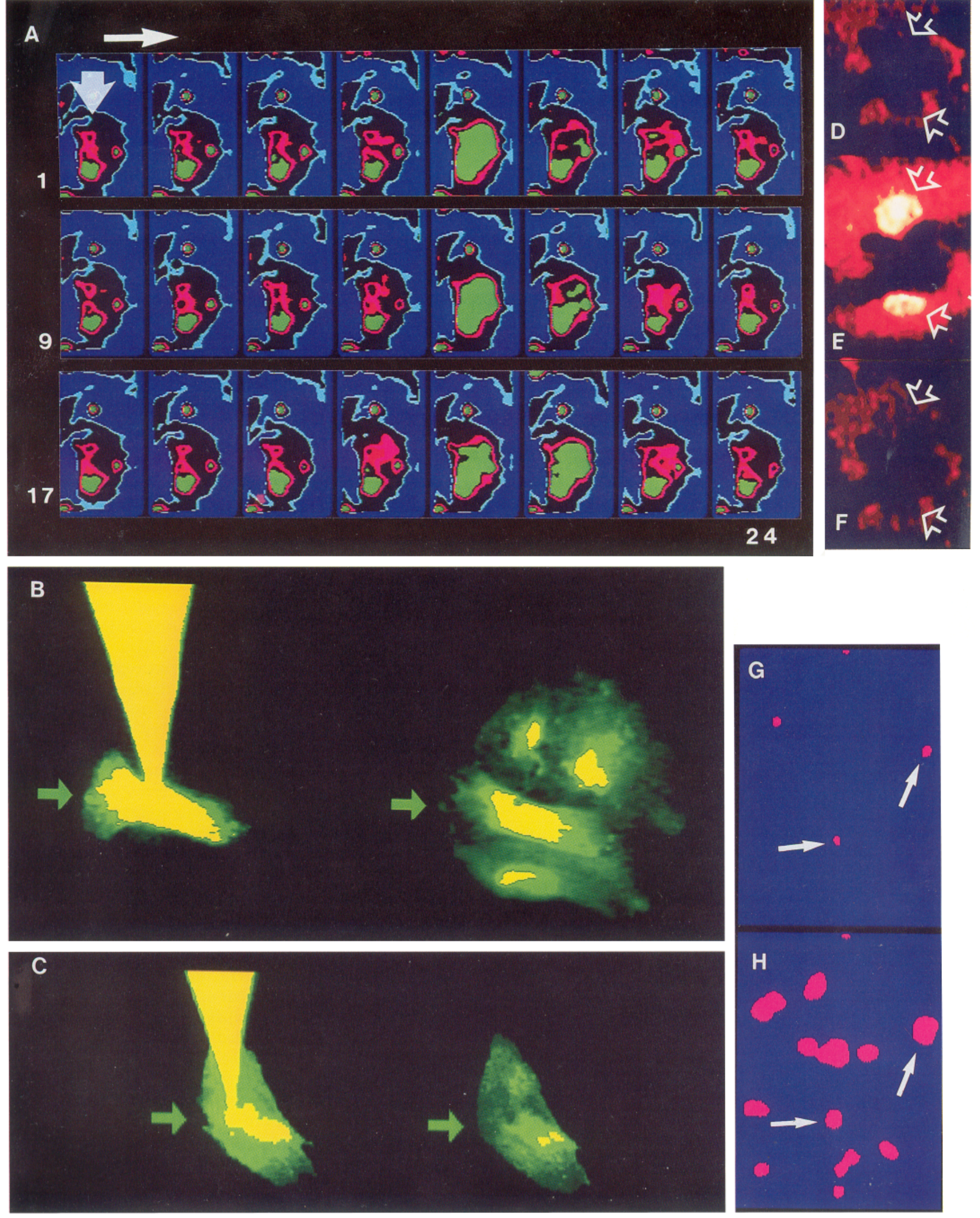


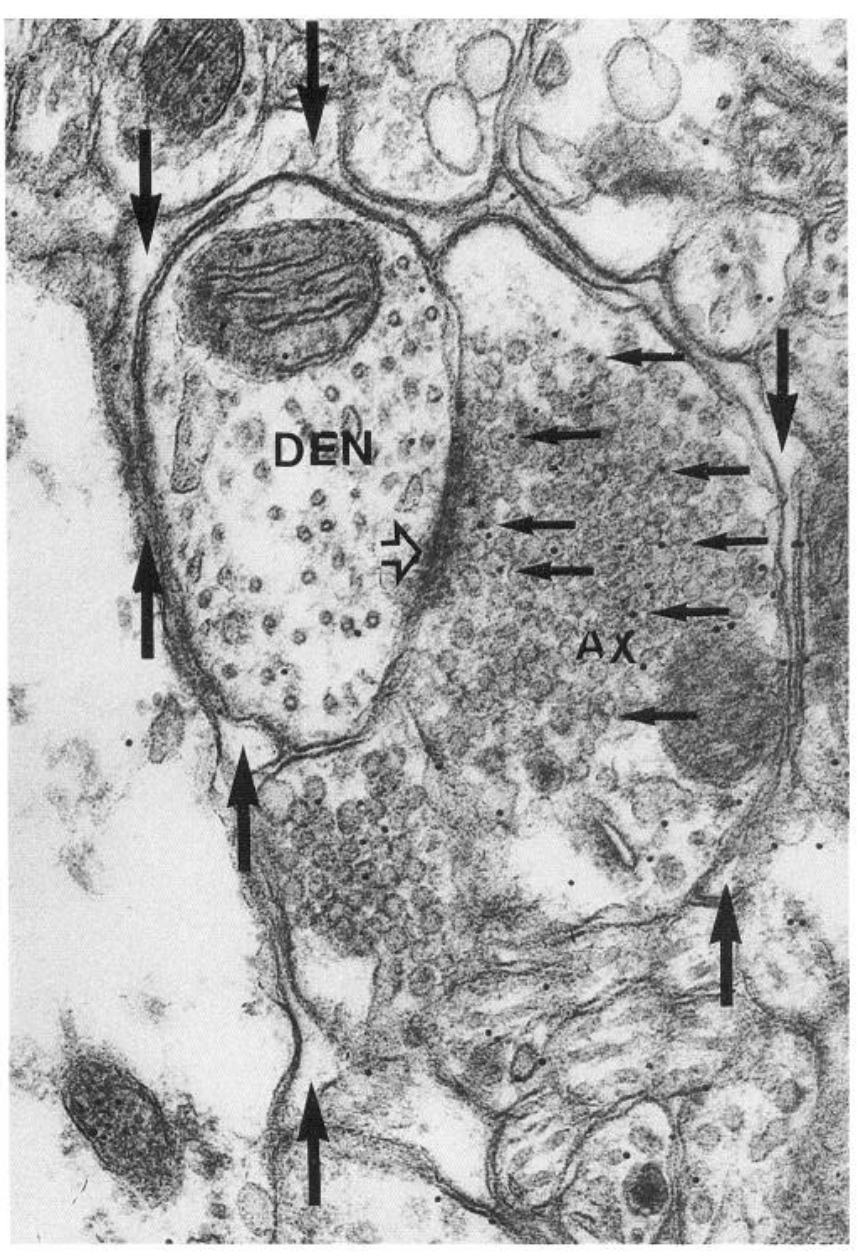

Figure 14. Glutamate-immunoreactive axon terminal $(A X)$ labeled with colloidal gold particles (small arrows) makes synapse (open arrow) with dendrite $(D E N)$. The synaptic complex is isolated from $\mathrm{SCN}$ neuropil by astrocyte processes (large arrows). The number of gold particles over the immunoreactive axon is eight times greater than over other cellular processes in this micrograph. Myelinated axons in the optic chiasm, probably of retinal origin, also showed glutamate immunoreactivity.

could eliminate periodic oscillations that would return in the absence of GABA, whereas glutamate set the mean intracellular $\mathrm{Ca}^{2+}$ of the oscillating neuron at a higher level. These amino acid transmitters, glutamate and GABA, found in large numbers of presynaptic terminals surrounded by astrocytes in the $\mathrm{SCN}$, influence both the baseline level of intracellular $\mathrm{Ca}^{2+}$ as well as the ultradian $\mathrm{Ca}^{2+}$ oscillations.

That circadian rhythms may be related to ultradian oscillations is suggested by the observation that per mutations that eliminate or alter circadian rhythms in Drosophila (Konopka and Benzer, 1971) also disturb an ultradian rhythm of the flies (Kyriacou and Hall, 1980). Interestingly, the per gene is expressed both in neurons and in glial cells in the fly brain (Zerr et al., 1990). Recent experiments with fly genetic mosaics suggest that expression of per in glia without detectable expression in neurons may be sufficient for weak manifestation of circadian behavioral rhythms in Drosophila, although normal circadian rhythms are probably associated with per expression in both glia and neurons. Drosophila glia expressing per are postulated to play a role in coupling the activity of pacemaker neurons ( $\mathrm{J}$. Hall, personal communication; Ewer et al., 1992).
Astrocyte modulation of neural activity. If astrocytes are involved in SCN function, they must be in communication with neurons since the output of the clock clearly involves neuronal efferent projections (Schwartz et al., 1987; Meijer and Rietveld, 1989; Schwartz, 1991). With ultrastructural immunocytochemistry, we showed here that in the mature $\mathrm{SCN}$, astrocytes are in close contact with axon terminals and surround glutamate-immunoreactive axons in synaptic contact with dendrites. We have no direct evidence that $\mathrm{SCN}$ astrocytes modulated neuronal activity. Three hypothetical models involving changes in intracellular $\mathrm{Ca}^{2+}$ and secondary changes in extracellular potassium, arachidonic acid or a metabolite, or calcium are suggested here. These models are not mutually exclusive and could underlie glial modulation of neural activity. In the potassium model (Fig. $15 A$ ), an increase in intracellular $\mathrm{Ca}^{2+}$ acts in concert with astrocyte depolarization induced by glutamate or other transmitters (Bowman and Kimelberg, 1984; Kettenmann and Schachner, 1985; Usowicz et al., 1989) to open enough $\mathrm{Ca}^{2+}$-activated potassium channels (Quandt and MacVicar, 1986; Nowak et al., 1987; Barres et al., 1988) to significantly alter the potassium concentration of the extracellular space between astrocytes and neurons. The second model (Fig. $15 B$ ) is based on intracellular $\mathrm{Ca}^{2+}$ rises in glia that would directly activate phospholipase $\mathrm{A}_{2}$, thereby liberating arachidonic acid from astrocytes (Axelrod et al., 1988; Bruner and Murphy, 1990). Similarly, arachidonic acid is released from neurons after stimulation of the NMDA receptor by glutamate (Dumuis et al., 1988). Peptide transmitters may also increase $\mathrm{Ca}^{2+}$-dependent arachidonic acid release from astrocytes, leading to an increased extracellular glutamate level (Marin et al., 1991). Arachidonic acid or a metabolite inhibits the astrocyte glutamate/sodium uptake (Barbour et al., 1989). As glial uptake of neurotransmitter amino acids is a major route of transmitter inactivation, reduced uptake would lead to a net rise in extracellular glutamate concentrations, thereby influencing neuronal excitability. A third possibility (Fig. $15 \mathrm{C}$ ) is that astrocytes may exercise some regulation of extracellular $\mathrm{Ca}^{2+}$ by virtue of slow synchronized $\mathrm{Ca}^{2+}$ uptake that could potentially influence transmitter release at synaptic junctions. $\mathrm{Ca}^{2+}$ uptake by astrocytes around synaptic complexes may reduce extracellular $\mathrm{Ca}^{2+}$, leading to a decrease in neurotransmitter release. SCN glial cells have long regions of apposition to neurons, with an extracellular distance of less than $20 \mathrm{~nm}$. The volume of the total extracellular space between a neuron and glial cell is very small $\left(0.002 \mu \mathrm{m}^{3}\right.$ over a $10 \mu \mathrm{m}^{2}$ area), facilitating any neuronal response to astrocyte-mediated changes in extracellular potassium, glutamate, or calcium.

Coupled astrocyte oscillators. We found ultradian oscillations in both neurons and glia cultured from SCN cells. Mathematical models can be used to demonstrate that the period of an aggregate rhythm from a population of oscillators may be faster or longer than any individual oscillator in the group (Winfree, 1967), allowing a group of coupled oscillators, neurons or glia, to form an aggregate circadian rhythm. Coupling also can lead to a precise aggregate rhythm by entraining the individual oscillators that would otherwise be significantly hampered by stochastic processes (Winfree, 1967). Mathematical modeling has suggested that high-frequency oscillators with periods within the same range as those shown in the present article for SCN cells may be the basis for a low-frequency oscillator such as a circadian oscillator (Pavlidis, 1969). Since a mechanism exists for integrating $\mathrm{Ca}^{2+}$ transients (Lisman and Goldring, 1988), precise ultradian oscillations could form the basis for a circadian 
A. POTASSIUM MODEL

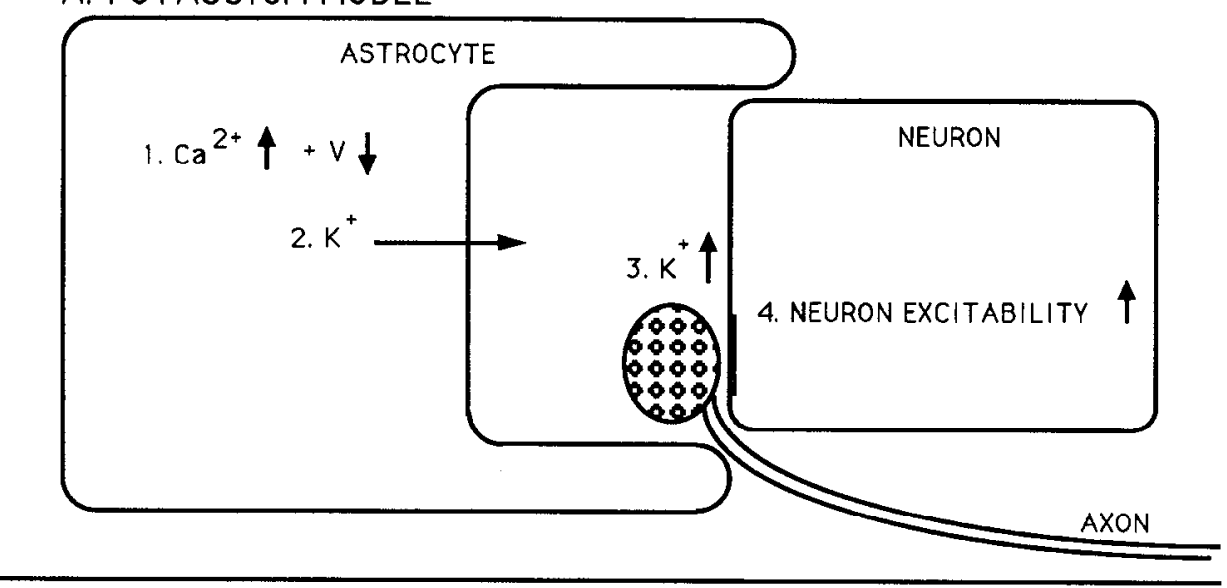

B. ARACHIDONIC ACID MODEL

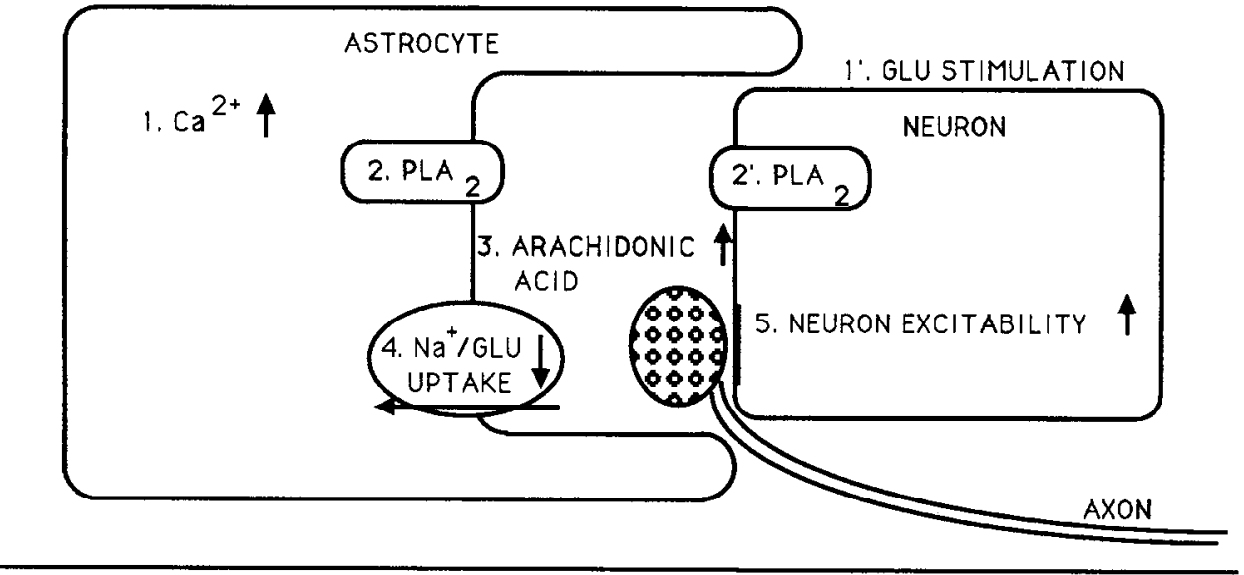

C. CALCIUM MODEL

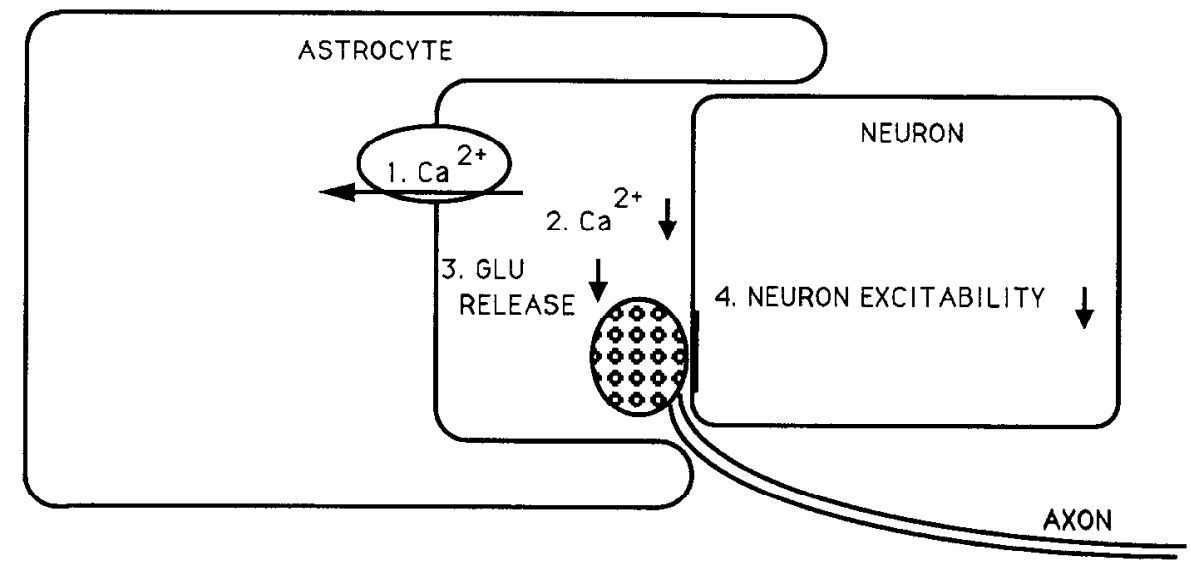

Figure 15. Three hypothetical models show how SCN astrocytes might modulate neuronal activity. The numbers in each model indicate the general sequence of events. Possible increases or decreases in neuronal excitability are indicated by the vertical arrows in the neurons; ion movement is indicated by horizontal arrows. Under certain temporal or concentration conditions, the direction of excitability could be postulated to be in the direction opposite to that shown. rhythm. Coupling cellular oscillators also appears possible. For instance, liver cells are capable of synchronous and periodic $\mathrm{Ca}^{2+}$ secretion in response to the same agonist (Graf et al., 1987) that causes cyclical $\mathrm{Ca}^{2+}$ transients in single liver cells (Woods et al., 1987). Like liver cells, SCN astrocytes are extensiveìy coupled by gap junctions, both in vivo and in vitro, and thus might couple their individual oscillations into an aggregate rhythm. On a microscopic scale, we found that the period of regular oscillations of individual astrocytes could be greatly increased by the glutamate, 5-HT, or ATP induction of intercellular waves of $\mathrm{Ca}^{2+}$. These waves moving through coupled astrocytes increased the average period from about $14 \mathrm{sec}$ to about
$60 \mathrm{sec}$ or longer, demonstrating that astrocyte intercellular communication plays a significant role in the alteration of the average period between the $\mathrm{Ca}^{2+}$ peaks. Waves of $\mathrm{Ca}^{2+}$ have been reported in other cells, where they appear to be dependent on gap junctions between cells, and may utilize inositol 1,4,5-triphosphate to carry the message across the gap junctions (Berridge and Irvine, 1989; Charles et al., 1991). That the $\mathrm{Ca}^{2+}$ wave may move between SCN glia through gap junctions is consistent with our confirmation in the present study of dye coupling between these cells. Substances that uncouple gap junctions eliminate the intercellular $\mathrm{Ca}^{2+}$ waves (Finkbeiner, 1991). The possibility that astrocytes with different transmitter responses may 
have divided faster than others in culture makes it difficult to predict the relative percentage of astrocytes that might respond to transmitters in adult tissue.

Neuron and glial role in SCN function. The possible involvement of astroglia in SCN function has not been previously explored and, while it may appear unlikely, merits some examination. When TTX was administered to the SCN, cells of the SCN continued to keep time, but their ability to drive behavioral and physiological circadian rhythms was lost (Schwartz et al., 1987; Meijer and Rietveld, 1989; Schwartz, 1991). Similarly, TTX administration to SCN explants reduced peptide secretion, but did not alter the phase of vasopressin secretion when a rhythm could be detected after cessation of TTX (Earnest et al., 1991). Since TTX blocks sodium-dependent action potentials and axonal conduction (Katz and Miledi, 1967), SCN neurons cannot communicate with each other by conventional neurochemical transmission, yet when tetrodotoxin is removed, behavioral cycles continue as if the clock cells were keeping time but were unable to send this message to other parts of the brain. In the present study, we found that TTX does not block the regular oscillations of $\mathrm{SCN}$ astrocytes, and similarly has no detectable effect on long-distance intercellular communication between astrocytes. In biological clocks in other species, gap junctions have been a regular feature, and are found in cellular circadian clocks of the Bulla eye (Jacklet and Geronimo, 1971; Jacklet and Colquhoun, 1983) and in the avian pineal (Takahashi and Menaker, 1984), and have been postulated to mediate the function of the Drosophila clock gene per (Bargiello et al., 1987). In contrast to SCN glia, neurons of the SCN have shown little evidence for gap junctions (van den Pol, 1980). If new ways of detection are successful at demonstrating interneuronal gap junctions in the SCN, this would add another dimension to cellular interaction here.

SCN glia appear to be different than glia from the surrounding hypothalamus as shown by the strong immunoreactivity for glial fibrillary acidic protein in the SCN compared with the immediately adjacent hypothalamus (Morin et al., 1989). Furthermore, glia in other parts of the brain are estimated to occur in numbers 10 times greater than neurons (Kuffler et al., 1984). In sharp contrast, in the present study we found fewer glial cells than neurons in the SCN. SCN glia also appear to be functionally different than those in other parts of the brain. Whereas virtually all (99-100\%) hippocampal astrocytes responded to glutamate under culture conditions similar to those described in the present experiment (Cornell-Bell et al., 1990), a smaller percentage of cells from SCN cultures show a $\mathrm{Ca}^{2+}$ response to glutamate. Those SCN astrocytes that do not respond to glutamate may respond to 5-HT or ATP; we did not compare hippocampal astrocytes with 5-HT or ATP. The communication between specific glial partners in vitro may be mirrored in the brain. Based on Golgi impregnations, gold sublimate staining, electron microscopy (van den Pol, 1980), cell counts, and glial fibrillary acidic protein immunostaining, single glial cells may interdigitate between neurons and surround axodendritic synaptic complexes, and thereby influence hundreds of SCN neurons. We find that not only can glutamate induce intercellular waves of $\mathrm{Ca}^{2+}$, as also found in the hippocampus (Cornell-Bell et al., 1990), but of particular interest, 5-HT and ATP can also induce these waves in cultured SCN astrocytes, leading to long-distance astrocyte communication. Since the response of astrocytes to the application of these substances is heterogeneous, one may elicit waves of $\mathrm{Ca}^{2+}$ between subsets of glia based on their se- lective transmitter response. The possibility of specific anatomical pathways of glial signaling, based on selective response to different transmitters, merits experimental attention, not only with regard to local circuit cellular interactions in the SCN, but also in other regions of the brain. Recent experiments on hippocampal slices have demonstrated a direct influence of presumptive glutamatergic neurons on astrocyte $\mathrm{Ca}^{2+}$; electrical stimulation of axons initiated $\mathrm{Ca}^{2+}$ waves in astrocytes near the axon terminals (Dani et al., in press).

Orchestrated cellular rhythms of 2-deoxyglucose uptake in the SCN are found at birth (Reppert and Schwartz, 1984). Whereas glial cells develop later than neurons in most parts of the hypothalamus, they may be found early in the SCN (Altman and Bayer, 1986) and in the adjacent optic chiasm (Vaughn and Peters, 1971), from which long astrocyte processes reach into the SCN (van den Pol, 1980). 2-Deoxyglucose rhythms are unlikely to be coordinated by synaptic interaction, which is rare at this stage of development (Moore, 1991); an alternative substrate for cellular orchestration is the gap junction present between developmentally immature cells.

In general, a primary purpose of cellular oscillators and intercellular waves of $\mathrm{Ca}^{2+}$ appears to be related to intercellular communication, and to increased cell synchrony. In this regard, the incorporation of this type of information could be of potential use in an area of the brain involved in timekeeping, and integration of astrocytes may lend greater stability to an oscillator based on rapidly responding neurons and astrocytes that show a slower response. Different regions of the brain appear to use similar physiological mechanisms, ion channels, and transmitters to perform different functions, in large part based on specific complex circuitry. As with other brain loci, the SCN is unique in the constellation of afferent and efferent axons, and local circuit interactions within the nucleus. Whether the ability of the SCN to drive circadian rhythms is due to some undiscovered cellular feature, or to its unique organization, remains to be determined.

The data presented here show dynamic responses and cellular communication between SCN glia induced by transmitters found in the SCN. These data suggest that the inclusion of both glial cells and neurons in models of SCN function may provide a more complete representation of cellular interaction in the biological clock. In both types of cells, $\mathrm{Ca}^{2+}$ may act as a critical agent mediating the influence of many neuroactive substances and orchestrating a number of intracellular mechanisms.

\section{References}

Aghajanian GK, Bloom FE, Sheard MH (1969) Electron microscopy of degeneration within the serotonin pathway of rat brain. Brain Res $13: 266-273$.

Altman J, Bayer SA (1986) The development of the rat hypothalamus. Adv Anat Embryol Cell Biol 100:1-178.

Axelrod J, Burch RM, Jelsema CL (1988) Receptor-mediated activation of phospholipase A2 via GTP-binding proteins: arachidonic acid and its metabolites as second messengers. Trends Neurosci 11: $117-123$

Barbour B, Szatkowski M, Ingledew N, Atwell D (1989) Arachidonic acid induces a prolonged inhibition of glutamate uptake into glial cells. Nature 342:918-920.

Bargiello TA, Saez L, Baylies MK, Gasic G, Young MW, Spray DC (1987) The Drosophila clock gene per affects intercellular junctional communication. Nature 328:686-691.

Barres BA, Chun LLY, Corey DP (1988) Ion channel expression by white matter glia. I. Type 2 astrocytes and oligodendrocytes. Glia 1: $10-30$. 
Berridge MJ, Galione A (1988) Cytosolic calcium oscillators. FASEB J 2:3074-3082.

Berridge MJ, Irvine RF (1989) Inositol phosphates and cell signalling. Nature 341:197-205.

Bowman CL, Kimelberg HK (1984) Excitatory amino acids directly depolarize rat brain astrocytes in primary culture. Nature 311:656659.

Bruner G, Murphy S (1990) ATP-evoked arachidonic acid mobilization in astrocytes is via a P-purinergic receptor. J Neurochem 55: $1569-1575$.

Burnstock G (1986) Purines as cotransmitters in the adrenergic and cholinergic neurones. Prog Brain Res 68:193-203.

Cahill GM, Menaker M (1987) Kynurenic acid blocks suprachiasmatic nucleus responses to optic nerve stimulation. Brain Res 410:125-129.

Charles AC, Merrill JE, Dirksen ER, Sanderson MJ (1991) Intercellular signaling in glial cells: calcium waves and oscillations in response to mechanical stimulation and glutamate. Neuron 6:983-992.

Chay TR (1990) Effect of compartmentalized $\mathrm{Ca}^{2+}$ ions on electrical bursting activity of pancreatic B-cells. Am J Physiol 258:C955-C965.

Choi DW (1988) Glutamate neurotoxicity and diseases of the nervous system. Neuron 1:623-634.

Cline HT, Tsien RW (1991) Glutamate-induced increases in intracellular $\mathrm{Ca}^{2+}$ in cultured frog tectal cells mediated by direct activation of NMDA receptor channels. Neuron 6:259-267.

Cornell-Bell AH, Finkbeiner SM (1991) $\mathrm{Ca}^{2+}$ waves in astrocytes. Cell Calcium 12:185-204

Cornell-Bell AH, Finkbeiner SM, Cooper MS, Smith SJ (1990) Glutamate induces calcium waves in cultured astrocytes: long-range glial signaling. Science 247:470-473.

Dani J, Chernjavsky A, Smith SJ (in press) Neuronal activity triggers calcium waves in hippocampal astrocyte networks. Neuron, in press.

Decavel C, van den Pol AN (1990) GABA: a dominant transmitter in the hypothalamus. J Comp Neurol 302:1019-1037.

Dumuis A, Sebben M, Haynes L, Pin JP, Bockaert J (1988) NMDA receptors activate the arachidonic acid cascade system in striatal neurons. Nature 336:68-70.

Earnest DJ, Digiorgio SM, Sladek CD (1991) Effects of tetrodotoxin on the circadian pacemaker mechanism in suprachiasmatic explants in vitro. Brain Res Bull 26:677-682.

Ewer J, Frisch B, Hamblen-Coyle MJ, Rosbash M, Hall JC (1992) Expression of the period clock gene within different cell types in the brain of Drosophila adults and mosaic analysis of these cells' influence on circadian behavioral rhythms. J Neurosci, in press.

Finkbeiner SM (1991) Calcium-mediated glutamate responses in cultured hippocampus, pp 1-353. PhD thesis, Yale University.

Gabellini N, Facci L, Milani D, Negro A, Callegaro L, Skaper SD, Leon A (1991) Differences in induction of c-fos transcription by cholera toxin-derived cyclic AMP and $\mathrm{Ca}^{2+}$ signals in astrocytes and 3T3 fibroblasts. Exp Cell Res 19:210-217.

Gahwiler BH (1981) Organotypic monolayer cultures of nervous tissue. J Neurosci Methods 4:329-342.

Glaum SR, Holzwarth JA, Miller RJ (1990) Glutamate receptors activate $\mathrm{Ca}^{2+}$ mobilization and $\mathrm{Ca}^{2+}$ influx into astrocytes. Proc Natl Acad Sci USA 87:3454-3458.

Goldbeter A, Dupont G, Berridge MJ (1990) Minimal model for signal-induced $\mathrm{Ca}^{2+}$ oscillations and for their frequency encoding through protein phosphorylation. Proc Natl Acad Sci USA 87:1461-1465.

Graf P, vom Dahl S, Sies H (1987) Sustained oscillations in extracellular calcium concentrations upon hormonal stimulation of perfused rat liver. Biochem J 241:933-936.

Grapengiesser E, Glyfe E, Hellman B (1989) Three types of cytoplasmic $\mathrm{Ca}^{2+}$ oscillations in stimulated pancreatic B-cells. Arch Biochem Biophys 268:404-407.

Jacklet J, Colquhoun W (1983) Ultrastructure of photoreceptors and circadian pacemaker neurons in the eye of a gastropod, Bulla. J Neurocytol 12:673-696.

Jacklet JW, Geronimo J (1971) Circadian rhythm: population of interacting neurons. Science 174:299-302.

Jensen AM, Chiu SY (1990) Fluorescence measurement of changes in intracellular calcium induced by excitatory amino acids in cultured cortical astrocytes. J Neurosci 10:1165-1175.

Katz B, Miledi R (1967) A study of synaptic transmission in the absence of nerve impulses. J Physiol (Lond) 192:407-436.

Kettenman H, Schachner M (1985) Pharmacological properties of gamma-aminobutyric acid-, glutamate-, and aspartate-induced de- polarizations in cultured astrocytes. J Neurosci 5:3295-3301.

Kim YI, Dudek FE (1989) Antagonism of fast excitatory postsynaptic potentials in suprachiasmatic nucleus neurons by excitatory amino acid antagonists. Soc Neurosci Abstr 15:1088.

Konopka RJ, Benzer S (1971) Clock mutants of Drosophila melanogaster. Proc Natl Acad Sci USA 68:2112-2116.

Kornhauser JM, Nelson DE, Mayo KE, Takahashi JS (1990) Photic and circadian regulation of $c-f o s$ gene expression in the hamster suprachiasmatic nucleus. Neuron 5:127-134.

Kuffler SW, Nicholls JG, Martin AB (1984) From neuron to brain. Sunderland, MA: Sinauer.

Kyriacou CP, Hall JC (1980) Circadian rhythm mutations in Drosophila melanogaster affect short-term fluctuations in the male's courtship song. Proc Natl Acad Sci USA 77:6729-6733.

Lisman JE, Goldring MA (1988) Feasibility of long-term storage of graded information by the $\mathrm{Ca}^{2+} /$ calmodulin-dependent protein kinase molecules of the postsynaptic density. Proc Natl Acad Sci USA 85: $5320-5324$.

Marin P, Delumeau JC, Tence M, Cordier J, Glowinski J, Premont J (1991) Somatostatin potentiates the $a_{1}$-adrenergic activation of phospholipase $\mathrm{C}$ in striatal astrocytes through a mechanism involving arachidonic acid and glutamate. Proc Natl Acad Sci USA 88:90169020 .

McCarthy KD, Salm AK (1991) Pharmacologically-distinct subsets of astroglia can be identified by their calcium response to neuroligands. Neuroscience 41:325-333

Meijer JH, Rietveld WJ (1989) Neurophysiology of the suprachiasmatic circadian pacemaker in rodents. Physiol Rev 69:671-707.

Meijer JH, van der Zee EA, Dietz M (1988) Glutamate phase shifts circadian activity rhythms in hamsters. Neurosci Lett 86:177-183.

Moore RY (1991) Development of the suprachiasmatic nucleus. In: The suprachiasmatic nucleus: the mind's clock (Klein D, Moore R, Reppert S, eds), pp 391-404. Oxford: Oxford UP.

Moore RY, Eichler VB (1972) Loss of circadian adrenal corticosterone rhythm following suprachiasmatic nucleus lesions. Brain Res 42:201206

Morin LP, Johnson RF, Moore RY (1989) Two brain nuclei controlling circadian rhythms are identified by GFAP immunoreactivity in hamsters and rats. Neurosci Lett 99:55-60.

Nowak L, Ascher P, Berwald-Netter Y (1987) Ionic channels in mouse astrocytes in culture. J Neurosci 7:101-109.

Ottersen OP (1989) Quantitative electron microscopic immunocytochemistry of neuroactive amino acids. Anat Embryol 180:1-15.

Palkovits M (1976) Determination of axon terminal density in the central nervous system. Brain Res 108:413-417.

Pavlidis T (1969) Populations of interacting oscillators and circadian rhythms. J Theor Biol 22:418-436.

Peterson GM, Moore RY (1980) Sclective cffects of kainic acid on diencephalic neurons. Brain Res 202:165-182.

Pittendrigh CS (1974) Circadian oscillations in cells and the circadian organization of multicellular systems. In: The neurosciences: third study program (Schmitt FO, Worden FG, eds), pp 437-458. Cambridge, MA: MIT Press.

Putney JW (1986) A model for receptor-regulated calcium entry. Cell Calcium 7:1-12.

Quandt FN, MacVicar BA (1986) Calcium activated potassium channels in cultured astrocytes. Neuroscience 19:29-41.

Rea M (1989) Light increases fos-related protein immunoreactivity in the rat suprachiasmatic nucleus. Brain Res Bull 23:577-580.

Reppert SM, Schwartz WJ (1984) The suprachiasmatic nuclei of the fetal rat: characterization of a functional circadian clock using ${ }^{14} \mathrm{C}$ labeled deoxyglucose. J Neurosci 4:1677-1682.

Rusak B, Zucker I (1979) Neural regulation of circadian rhythms. Physiol Rev 59:449-526.

Rusak B, Robertson HA, Wisden W, Hunt SP (1990) Light pulses that shift rhythms induce gene expression in the suprachiasmatic nucleus. Science 248:1237-1240.

Schwartz WJ (1991) Further evaluation of the tetrodotoxin-resistant circadian pacemaker in the suprachiasmatic nuclei. J Biol Rhythms $6: 149-158$.

Schwartz WJ, Gross RA, Morton MT (1987) The suprachiasmatic nuclei contain a tetrodotoxin-resistant circadian pacemaker. Proc Natl Acad Sci USA 84:1694-1698.

Sherman A, Rinzel J, Keizer J (1988) Emergence of organized bursting 
in clusters of pancreatic B-cells by channel sharing. Biophys J 54: $411-425$.

Shibata S, Shiratsuchi A, Liou SY, Ueki S (1984) The role of calcium ions in circadian rhythm of suprachiasmatic nucleus neuron activity in rat hypothalamic slices. Neurosci Lett 52:181-184.

Shibata S, Liou SY, Ueki S (1986) Influence of excitatory amino acid receptor antagonists and of baclofen on synaptic transmission in the optic nerve to the suprachiasmatic nucleus in slices of rat hypothalamus. Neuropharmacology 25:403-409.

Shibata S, Newman GC, Moore RY (1987) Effects of calcium ions on glucose utilization in the rat suprachiasmatic nucleus in vitro. Brain Res 426:332-338.

Somogyi P, Halasy K, Somogyi J, Storm-Mathisen J, Ottersen OP (1986) Quantification of immunogold labelling reveals enrichment of glutamate in mossy and parallel fibre terminals in cat cerebellum. Neuroscience 19:1045-1050.

Stephan FK, Zucker I (1972) Circadian rhythms in drinking behavior and locomotor activity of rats are eliminated by hypothalamic lesions. Proc Natl Acad Sci USA 69:1583-1586.

Takahashi JS, Menaker M (1984) Multiple redundant circadian oscillators within the isolated avian pineal gland. J Comp Physiol 154 $435-440$.

Trejo JA, Brown JII (1991) c-fos and c-jun are induced by muscarinic receptor activation of protein kinase $\mathrm{C}$ but are differentially regulated by intracellular calcium. J Biol Chem 266:7876-7882.

Usowicz MM, Gallo V, Cull-Candy SG (1989) Multiple conductance channels in type- 2 cerebellar astrocytes activated by excitatory amino acids. Nature 339:380-383.

van den Pol AN (1980) The hypothalamic suprachiasmatic nucleus of rat: intrinsic anatomy. J Comp Neurol 191:661-702.

van den Pol AN (1989) Neuronal imaging with colloidal gold. J Microse 155:27-59.

van den Pol AN (1991) Glutamate and aspartate immunoreactivity in hypothalamic presynaptic axons. J Neurosci 11:2087-2101. van den Pol AN, DecavelC (1990) Synaptic interaction between chemically defined neurons: dual ultrastructural immunocytochemical approaches. In: Methods for the analysis of neuronal microcircuits and synaptic interactions (Bjorklund A, Hokfelt T, Wouterlood F, van den Pol AN, eds), pp 199-272. Amsterdam, Elsevier.

van den Pol AN, Powley T (1979) A fine-grained anatomical analysis of the role of the rat suprachiasmatic nucleus in circadian rhythms of feeding and drinking. Brain Res 160:307-326.

van den Pol AN, Tsujimoto K (1985) Neurotransmitters of the hypothalamic suprachiasmatic nucleus: immunocytochemical analysis of 25 neuronal antigens. Neuroscience 15:1049-1086.

van den Pol AN, di Porzio U, Rutishauser U (1986) Growth cone localization of NCAM on central nervous system neurons in vitro. J Cell Biol 102:2281-2294.

van den Pol AN, Wuarin JP, Dudek FE (1990) Glutamate, the dominant excitatory transmitter in neuroendocrine regulation. Science 250:1276-1278.

van den Pol AN, Cornell-Bell A, Finkbeiner S (1991) Ultradian calcium oscillations in suprachiasmatic nucleus cells. Soc Neurosci Abstr $17: 25$

Vaughn JE, Peters A (1971) The morphology and development of neuroglial cells. In: Cellular aspects of growth and differentiation (Pease DC, ed), pp 103-140. Los Angeles: University of California Press.

Winfree AT (1967) Biological rhythms and the behavior of populations of coupled oscillators. Theor Biol 16:15-42.

Woods NM, Cuthbertson RKS, Cobbold PH (1987) Agonist-induced oscillations in the cytoplasmic free calcium concentration in single rat hepatocytes. Cell Calcium 8:79-100.

Wray S, Gahwiler BH, Gainer H (1988) Slice cultures of LHRH neurons in the presence and absence of brainstem and pituitary. Peptides 9:1151-1175

Zerr DM, Hall JC, Rosbash M, Siwicki KK (1990) Circadian fluctuations of period protein immunoreactivity in the $\mathrm{CNS}$ and the visual system of Drosophila. J Neurosci 10:2749-2762. 